

\title{
$92 \frac{80}{6}$
}

\author{
Digitized by the Internet Archive \\ in 2009 with funding from \\ Boston Library Consortium Member Libraries
}




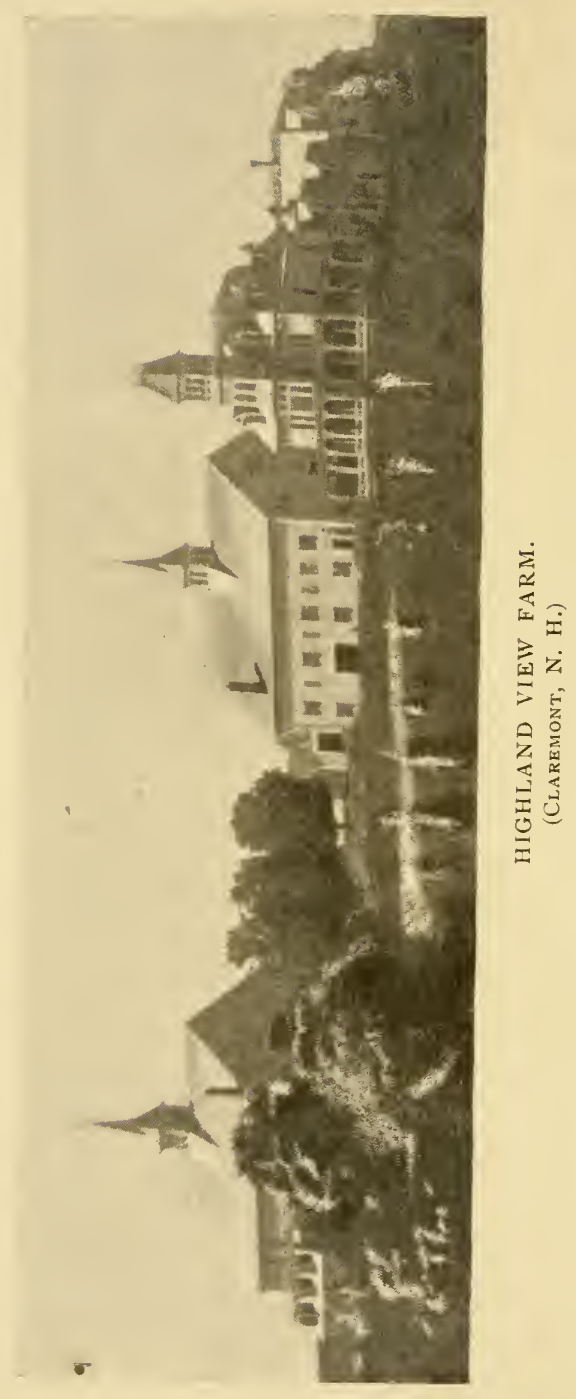




\section{CATALOGUE}

\section{STAND ARD-BRED}

\section{$-\mathrm{AT}-$ \\ Highland View Farm,}

WM. H. MOODY

Clatarement, N. H.

$\rightarrow 1891 \mathrm{k}$ 
PRESS OF

MILLS, KNIGHT \& CO.

BOSTON. 


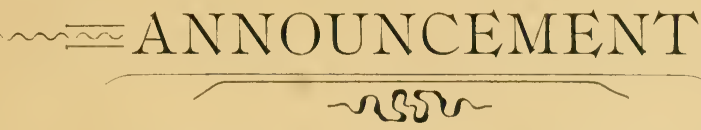

Highland View Stock Faris is located in Claremont, N. H., one mile from station, and consists of six hundred acres of highly improved land. The buildings have been constructed with a view to attractiveness as well as convenience, and sanitarily are wellnigh perfect. With good, never failing water supply, rich pasturage and ample yard room, the facilities for the breeding of trotting stock are unexcelled. The roads are excellently constructed throughout the town, besides which, there is on the farm as fast a half-mile track as is on any farm in the country; forty feet wide all the way, with fast stretches and turns, which are nicely graded.

From the buildings may be seen from any point of the compass the most picturesque views, including mountain, valley and river vistas, and altogether Highland View is excellently well adapted for a country seat. Visitors are welcome at all times save Sundays, when business is suspended and the stock cannot be shown. Those interested in breeding, developing or examining fine horses will, we feel assured, see much of interest here. The stock is bred in well tried lines, and individually as good as the breeding would suggest.

Excepting Evolutio, any animal in the collection is for sale, reasonably priced, on application.

WLT. H. MOODY, PROP'R.

TM. A. NEVINS, MANAGER.

- ClaretMont, N. H. JANUARY Ist, IS9I. 


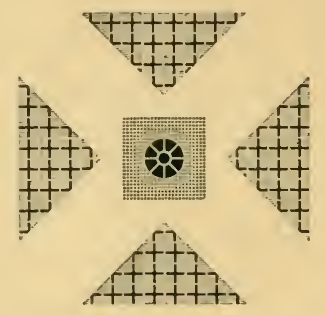




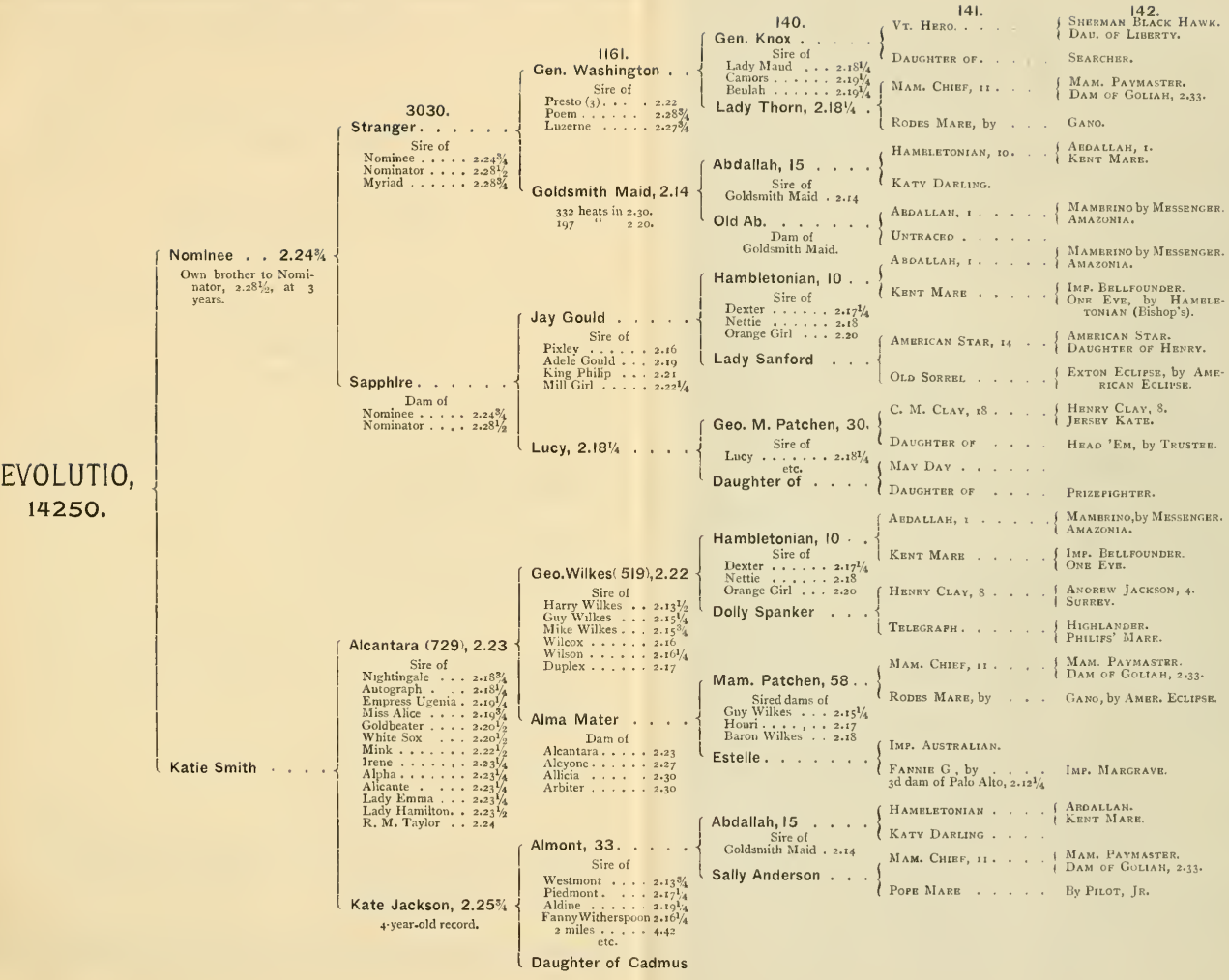





\section{S'TALLIONS.}

\section{EVOLUTIO, 14250.}

PRIVATE.

Chestnut stallion; foaled I888; bred at "Highlawn," Lee, Mass.

[STANDARd Bred, Rule 6.]

Sire, NOMINEE, 4150.

Record $2.243 / 4$.

Brother to Nominator, $2.2 \$ 1 / 4$, at three years old, $3^{\text {rd }}$ heat.

First Dam, Katie Sinth, by Alcantara, 729.

4-year record, 2.23 .

Sire of 21 trotters to enter the 2.30 list during $\mathrm{r} \$ 90$, beating the world's productive record.

Also sired dams of Prince Regent, $2.16 \frac{1}{2}$, winner of the $\$ 10.000$ Hartford Stake, and Ægon, 3-year record, $3 \mathrm{~d}$ heat, $2.181 / 4$, winner of all his races, and could beat 2.17.

Second Dam, Katie Jackson, Record, $2.25^{3}$, as a four-year-old.

Third Dam, FAnNy,

A noted show mare in Kentucky, winning many premiums. by Almont, 2.39 $\frac{3}{4}, 33$,

Sire of Fannie Witherspoon, 2.161/4, 2 -mile record 4.461/4, Piedmont, $2.17 \frac{1}{4}$ ( $\mathrm{I}$ in 2.30 list), Aldine, $2.191 / 4$ $\left(2.16 \frac{1}{2}\right.$ to pole), and 30 others in 2.30 list.

Sire of dam of Alabaster, t-year record, 2.I5, Catchfly, record 2.181/4, and others.

by CADMus.

A strain found prominently in Nelson, 2.10 $3 / 4$, the present stallion king, and Smuggler, 2.151/4, the ex-champion holder of that honor. 


\section{Nominee,}

First Dam, Sapphire,

Dam of Nominator, $2.281 / 4$, at 3 years.

Second Dam, Lucy, 2.1 $8 \frac{1}{4}$,

Dam of INHERITOR, sire of Montgomery, $2.20 \frac{1}{4}$.

Dam of SAPPHIRE, dam of Nominee,

$2.2+\frac{8}{4}$, Nominator, $2.28 \frac{1}{4}$.

Dam of Lucia, dam of Beulah,

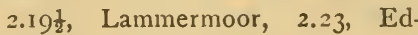
gardo, 2.27, Zoe (dam of Trapeze, $\left.2.29 \frac{1}{4}\right)$.

Third Dam, Daughter of Dam of Lucy, 2.1 $\$ \frac{1}{4}$.

Fourth Dam, Daughter of

\section{Alcantara, 729,}

Sire of

Autograph................... $\$ \frac{1}{4}$

Miss Alice..............2.19

White Sox.............2.20 $2 \frac{1}{2}$

Mink................2.22

Irene................2.23

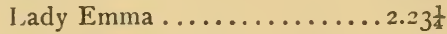

Alpha.................2.23 $\frac{1}{4}$

Alicante................2.23

Robt. M. Taylor............2.24

Alcazar................2.24

Alcagetta................2.25

Thornton............. 2.261

Wilkes Bee..............2.27

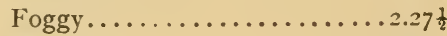

Mary S..................28

Etta.................2.2 $8_{\frac{1}{2}}$

Ariel..................2.28

Fillmore. .............2.29

Alcavalla ...............2.29

Alcantara, Jr............2.29 $\frac{1}{2}$ by Stranger,

Sire of Nominee, $2.243 / 4$, Nominator, $2.281 / 4$, Myriad, $2.283 / 4$.

by JAY GOULD, 2.20 $\frac{1}{2}$,

Sire of Pixley, 2.16, Adele Gould, 2:19, etc.

by Geo. M. Patchen, 2.23 $\frac{1}{2}$,

Sire of Lucy, 2.I $8 \frac{1}{4}$, Godfrey Patchen, sire of Hopeful, 2.14量, etc., etc.

Nore.-Montgomery is sire of Cleveland S., $2.26 \frac{1}{4}$.

MaY Day,

Sire of dam of Madame Dudley.

Prizefighter.

by George IVilkes, 519, 2.22, Sire of

Guy WILkES, 2.I $5 \frac{1}{4}$, sire of Sable Wilkes, 2.1 8 , he, sire of Freedom, one-year-old, $2.29 \frac{8}{4}$, fastest to date at the age.

WM. L., sire of Axtell, 2.12, champion three-year-old stallion record.

PACERS.

Nightingale..............2.18

Empress Eugenie...........2.19

Goldbeater...............2.20 $20 \frac{1}{2}$

Lady Hamilton..............2.23

Raven.................2.26 $26 \frac{1}{4}$

Bayard Wilkes.............2.26

Zero....................2.29

Attractive................2.29

Montezuma.................2.298 
Alcander ...............2.298

Estabrook ..............2.29

Queen Anne..............2.30

Joe Wilkes.............. 30

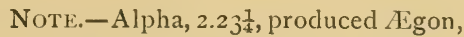

3.year record, 3d heat, $2.1 \$ \frac{1}{4}$.

Montezuma sired White Wings, 3-year record, 3d heat, $2.29 \frac{1}{4}$.

\section{Almont,}

First Dam, Sally Anderson,

Second Dam, Pope Mare, by Abdallah, i 5 ,

Sire of Goldsmith Maid, 2.I4.

by Mambrino Chief, i I,

Sire of Lady Thorne, 2.1 $\$ \frac{1}{4}$.

by PILot, JR., I 2 ,

Sire of dams of Maud S., 2.08是, Jay Eye See, 2.Io.

This breeding is unsurpassed in many directions. The ancestors were nearly all of developed speed, and were tried and found to be brilliant campaigners. As Stranger was by Gen. Washington, and out of Goldsmith Maid, record 2.14, 332 heats in or below 2.30, and Gen. Washington by Gen. Knox, $2.3 \frac{3}{4}$ (public trial, 2.24), out of Lady Thorne, 2.18 $\frac{1}{4}$, 106 heats in or below 2.30, and own sister to the phenomenal broodmare sire, Mam. Patchen. Nominee's dam, Sapphire, out of the great mare, Lucy, 2.1 $8 \frac{1}{4}, 62$ heats in or below 2.30. Now we get a combination of the blood-lines of the three Queens of the Turf during their day, a line to Geo. M. Patchen, Champion Stallion during his time, and another to Jay Gould, which was also stallion king at one time.

Alcantara leads the world's speed-producing record, and was by Geo. Wilkes, ex.champion stallion king, and the leading sire to date among sires of trotters; his dam, Alma Mater, by the leading extreme speed broodmare sire (as judged by the 2.20 list), Mam. Patchen, 58, is dam of Alcyone, 2.27, sire of Alcryone, 2.15 $\frac{1}{2}$, Iona, 2.17 $\frac{1}{4}$, etc., Arbiter, 230 , and Allicia, 2.30, second dam Estella, by Australian, third dam Fanny G. (also third dam of Palo Alto, 2.1 $2 \frac{1}{4}$ ), by Imp. Margrave. This includes, it will be seen, four direct lines to Hambletonian $\mathrm{o}$, the greatest sire of his time, and sire of Electioneer, George Wilkes, Happy Medium, Dictator, etc.; two strains to Alexander Abdallah, I5, opportunity considered, Hambletonian's best son; three strains to Mambrino 
Chief, Ir (once through his best daughter, and once through his best son); two lines to Henry Clay; one each to Pilot, Jr., r2, sire of dams of fastest and second fastest trotters ever foaled, American Star, 14 , sire of dams of Dexter, 2.17 $\frac{1}{4}$, Nettie, 2.18, Orange Girl, 2.20, Guy, 2.103. The famous sires, Geo. Wilkes, Almont, Mam. Chief, Abdallah, $\mathrm{r}_{5}$, and Mam. Patchen, are of themselves sufficient to form a gilt-edged pedigree, but add to this the outcrosses of pacing and enduring thoroughbred and it is complete.

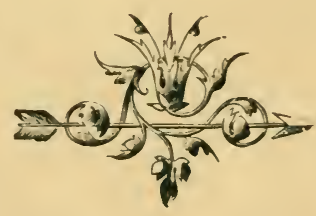




\section{EAGLE WILKES.}

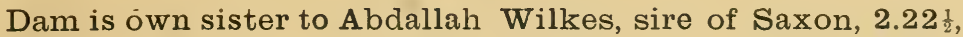

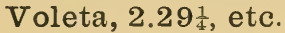

Bay stallion; foaled $188_{3}$; bred by Dr. Wm. Jarvis, Claremont, N. H. Owned at Highland View.

Sire, ALMONT EAGLE, 2.27.

Could show a 2.15 gait, and with a chance should have beaten 2.20 .

First Dam, Vesta Wilkes,

Sister to Abdallah Wilkes, trial, 2.29.

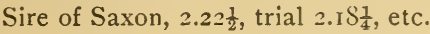

Second Dam, Marie,

Third Dam, Daughter of by Geo. Wilkes, 5 I 9 .

Record, 2.22.

Sire of Harry Wilkes, 2.I $3 \frac{1}{2}$, Guy Wilkes, 2.I $5 \frac{1}{4}$, Mike Wilkes, 2. I $5^{\frac{8}{4}}$,

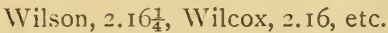

The leading sire of trotters and Hambletonian's best son.

by Wagner AbDallah,

Son of Jupiter Abdallah, sire of Result, 2.25, Prince, 2.27, Tom Moore, 2.2S. His dam by the 4-mile racer, Wagner.

Kentucky,

Son of the noted racer, Lexington.

Geo. Wilkes' best nick is with the Mambrino Chief blood; here we have it reversed. The Wilkes, on dam's side: backed by gamest of racing strains and crossed on sire's side to the double Mambrino Chief strains, with a Pilot, Jr., outcross, then direct to a foundation of great notoriety for stamina.

EAGLE Wilkes is not a large horse, but as handsome a horse as stands, of commanding appearance and absolutely perfect in anatomical construction everywhere. He is fast, stylish, and will be, or should be, a great sire. There's no speculation about him, for on each side it has been shown to be of speed-producing value. There are few in all this broad land like him, and none handsomer, according to those who have the right of experience to say it.

FOR SALE. 


\section{NAP○LEON.}

[STANDARD, RULE 6.]

Dark bay horse ; foaled 1885 ; bred by G. D. Frost, Bellows Falls, Vt.; stands 16 hands full.

Sire, ALMONT EAGLE, 2.27.

First Dam, Psyche, 2.27 $\frac{1}{4}$,

by BAYARD, $2.3 \mathrm{I} \frac{1}{2}, 53$,

Sire of Bliss, 2.2I $\frac{1}{2}$, Emma B., 2.22,

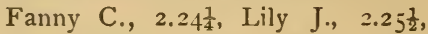

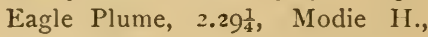
$2.29 \frac{1}{2}$, Aimee, 2.30; dams of Faust,

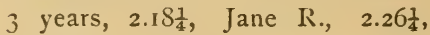
etc., etc.

Son of Pilot, Jr., I2. Sire of dams of 20 in 2.30 list.

Second Dam, Arabian Girl, Record, 2.40.

Third Dam, Dam of by CARNAC,

Son of Ashland (sire of dams of Edwin Thorne, 2.16 $\frac{1}{4}$, Black Cloud, 2. ( $\left.7 \frac{1}{4}\right)$, by Mam. Chief, I 1 .

SPotted Jin, 2.33.

Could trot in 2.25 .

Here we trace direct to the great broodmare fountains, Mambrino Chief, I I, three times, and to Pilot, Jr., I2, twice, with speedproducing dams all round. Almont Eagle and Psyche both developed performers both capable of faster records than attained at the time made, as their trials indicated each could beat 2.20. Back of all is another speed-producer, dam of Spotted Jim, 2.33, a horse trotted around half-mile tracks more to obtain purses than record; he could trot in $\mathbf{2 . 2 5}$ and faster, but was never allowed to trot there. Speed-producers denied first-rate opportunities are the very best examples of individuality to be found, and of far more value in a pedigree than fashionable strains which cannot substantiate by virtue of performance the trust put in the richness of breeding by patrons who wonder that they never got a trotter when those bred in similar lines go and perform creditably. NAPOLEON was retained, as he was well fortified with a high rate of natural speed, to prove what he now is, a trotter.

FOR SALE. 


\section{WLM. H. MTOODY, 9581.}

[STANDAR1), RULE 6.]

Brownish bay stallion; foaled, 1887 ; bred at Highland View; stands 16 hands full.

\section{Sire, VITTORIA.}

First Dam, MERMAID,

Trial, driven by J. J. Bowen, in 2.2S.

Second Dam, SEA FOAM,

Record $2.24 \frac{1}{4}$.

Could trot in 2.20 , or better, and won 24 hotly contested heats in 2.30 and faster. by Volunteer Boy.

Trial, 2.27; son of Volunteer, 55 .

by Young Columbus,

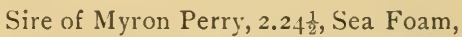

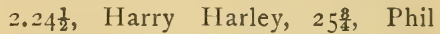

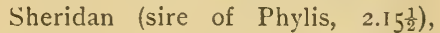

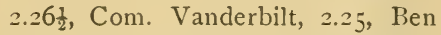

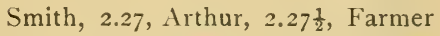
Boy, 2.2S, Fitzgerald, 2.30, Young Columbus, Jr., 2.30; dam of Ab-

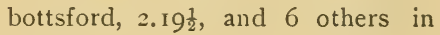
2.30 .

Third Dam, Daughter of
HaMBLETONIAN, 2, (HARRIS,)

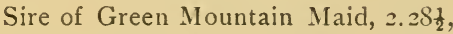
and 3 others also, dams of 6 in 2.30 .

There is decidedly an outcross here, and includes fast performers. Mermaid ought to have been in the list, but has been bred in preference to a turf career. The blood of Young Columbus breeds

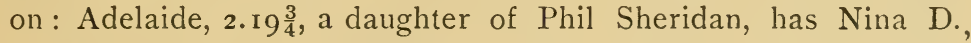

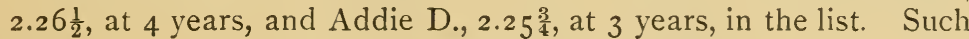
an outcross, when commingled with Hambletonian and Mambrino Chief blood, must result favorably, as it becomes stronger as a speed-productive factor.

This fellow is a royally handsome horse, excellently fashioned, bred and gaited for a fast performer, and knows nothing but trot. Good judges think him capable of a record in his four-year-old form inside the "circle which divides." He will be handled this coming season, and, barring accident, will be given a mark.

FOR SALE. 


\section{QUINTUPLE.}

[Stannard, Rule 6.]

Chestnut colt; foaled 1890 ; bred by S. W. Parlin, Phillips, Me. Sire, ALLECTUS, 3794.

Own brother to IRENE, $2.23 \frac{1}{4}$.

Dam, Hartelle,

Second Dam, Heartless, by Almont Eagle, 2.27,

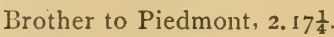

by HARTFORD,

Son of Rysdyk; sire of Clingstone, 2.14 .

Third Dam, Dam of Jersey Lily, by Telegraph,

$$
2 \cdot 34 \frac{1}{2}
$$

Fourth Dam, Daughter of
Son of Locomotive by Blucher.

Charlton Horse.

Could trot fast and draw heavy weight.

\section{ALLECTUS}

by Alcantara, Dan Iola, by Administrator, $2 \mathrm{~d}$ dam the famous progenitor, Jessie Pepper, by Mambrino Chief.

\section{JESSIE PEPPER'S PRODUCE.}

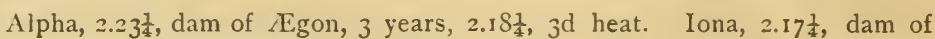
Acman, 3 years, 2.29

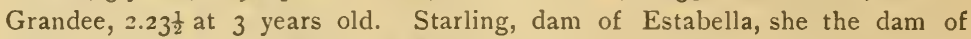

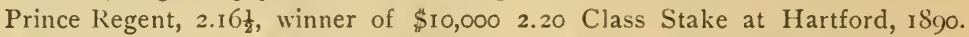
Wenonah, dam of Montezuma, 2.29多, sire of White Wings, 2.29 at 3 years.

\section{ALMA MATER'S ROLL OF HONOR.}

Alcantara, 33 in 2.30 list at 14 years of age, 21 of which entered in 1890 , beating all speed-productive records. Record at 4 years, 2.23 , last half, $1.06 \frac{1}{2}$. Alcyone, 2.27, sire of 15 in 2.30 list. Arbiter, record 2.30. Allicia, 2.30.

Quintuple traces five times to Mambrino Chief, five to Hambletonian, Io. To Mambrino Chief, through his best daughter really (breeding-on characteristics considered), Jessie Pepper.

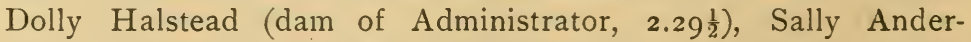
son (dam of Almont), Mag Ferguson (dam of Piedmont, 2.17 $\frac{1}{4}$, 
Almont Eagle, 2.27, Mammont 2 in 2.30 list), and through Alma Mater (4 in 2.30) to Mambrino Patchen, son of Mambrino Chief, and his best son as well. To Hambletonian through Geo.

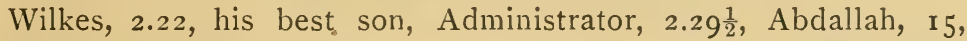
Rysdyk and Hartford's dam. In addition there are strains direct to Grey Eagle, Sir Archy and Diomed. He is individually one of the fastest gaited colts of his age to be found, look where we may, and extremely bloodlike, and in every way promising. He is ultrafashionably bred, possessing the best performing blood from Alcantara ( 21 in 2.30 list in 1890 ), and tracing directly to the greatest matron of the year, Jessie Pepper.

There is little to risk, for with opportunity he will become a trotter, and his opportunities on the Highland View mares are conceded to be first-class for the production of trotters, and the records show that the trotters descended from Jessie Pepper are among the gamiest and most level-headed ever to show in public. Prince Regent can trot in 2.r 4, as can Ægon, if not indeed faster; $2.23 \frac{1}{4}$ will not stop Irene - with another season she can undoubtedly enter the 2.20 list easily.

Taken all in all, there are few colts obtainable with as promising a speed inheritance as has this fellow, and with excellent bone structure and high finish we can but anticipate a brilliant future career for him either here or in the event of his being disposed of. In his two-year old form he will be allowed a few choice fillies from our stud.

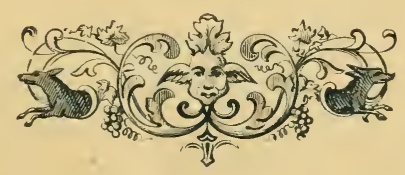




\section{REX NUTWOOD.}

Handsome rich bay; foaled $\mathrm{r} 887$; bred in Kentucky by W. H. Hill, Worcester, Mass; stands 16 hands; weighs r roo lbs.

[STANDARD, Rule 6.]

Sire, NUTWOOD, 600.

Record 2.1 $8 \frac{3}{4}$.

Sire of

WoODNUT.................. $26_{\frac{1}{2}}$

FELIX....................

Dawn..................... 2. 89

MAGGIE E................2.19星

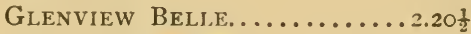

3 years, etc., etc.; also

Manager.................... $2.16 \frac{1}{2}$

(fastest 2-year record).

First Dam, Sister Ruth,

Second Dam, Sister MaC,

Sister to Lady Mac, 2.23, Mr. Vanderbilt's famous pole mate to Small Hopes.

Third Dam, Madonna,

Dam of Lady Mac, 2.23, held double team record with Small Hopes many years.
Belmont Boy.............2.15

(Pacers.)

Nutwood added i9 to his roll of 2.30 performers in $\mathrm{I} S 90-\mathrm{a}$ total to date of 49 in 2.30 .

by Jin Munroe,

Sire of Monroe Chief, 2.I $8 \frac{1}{4}$, Kitty Bates, 2.19, and 6 others.

by WHIRLWIND, $2.3 \circ \frac{1}{2}$,

Sire of dam of Maud Messenger, 2.16 $\frac{1}{4}$, and Pearl Madison, 2.27.

by UNTRACED.

Here is another pedigree rich in broodmare strains of great brilliancy: Nutwoon being out of the famous producer, Miss Russell, which produced the Queen of the Turf, Maud S., 2.08 $\frac{3}{4}$,

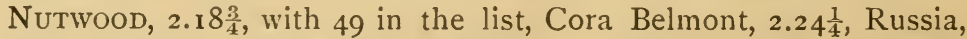
2.28. Besides these Lord Russell has sired several, including Kremlin, 2.22 $\frac{1}{2}$, trial, 2.18 at 3 years old. Nutula is dam of Maudlen, 2.25 $\frac{3}{4}$, and Mambrino Russell sired several, including 
Happy Russell, $2.21 \frac{1}{4}$, he sire of Happy Bee, 2-year record 2.29 $\frac{1}{4}$, on half-mile track. Nutbourne, trial, $2.26 \frac{1}{2}$, has two in the 2.30 list. A wonderful record of speed transmittance; and several others will undoubtedly be in the list, as Miss Russell is alive, and breeding each year. Nutwood was by Belmont, trial $2.28 \frac{1}{4}$, and his dam, Belle, by Mambrino Chief, produced McCurdy's Hamble-

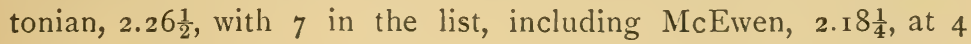
years, Belmont, with 35 in the list, and Bicara, the dam of Pancoast, $2.2 \mathrm{I} \frac{3}{4}$, famous as sire of Patron, 2.19 $\frac{1}{2}$, at three-years old, in a race; $2.14 \frac{1}{4}$, at 5 years, in a race. She was a daughter of the wonderful broodmare sire, Mambrino Chief, I I. REx Nutwood's third dam produced Lady Mac, 2.23. Turn where you may this pedigree bristles with speed ancestry, and individually he is a great young horse, and a promising candidate for turf success, possessing capabilities of high order as to speed. Nutwood sold at auction for $\$ \mathbf{2 2 , 0 0 0}$, and has stood at the head of popular sires for six seasons, and as evidence of his success commands a fee of $\$ 500$, with "book filled" for five years. A Nutwood weanling sold at private sale for $\$ 6,000$, highest figure ever obtained to date. That REx Nutwoon will develop into a great young horse, there can scarcely be raised a doubt, if no unseen accident overtakes him previous to maturity. Horses of his individuality, by Nutwood, are not obtainable save at phenomenally high prices.

FOR SALE.

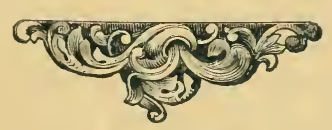




\section{SCUTARI, JR.}

Dark bay stallion; foaled 1883 ; bred by Wm. H. Moody, Claremont, N. H.

\section{Sire, SCUTARI.}

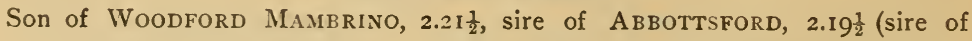
Conde, 2.20), Mambrino Dudley, 2.19年 (sire of Crescendo, 2.24), and others.

First Dam, Mary Curtis,

Second Dam, Daughter of Owned by Elijah Hoffman, Philadelphia, Pa. by Volunteer Boy,

Sire of dam of Fearnaught, 2.19, and obtained record his first heat in public, 2.19․․․

Black Sherman,

Son of Vt. Black Hawk, out of the Hammill Mare by son of Bellfounder.

Here's another pedigree built on the Mambrino Chief Hambletonian cross and with a Morgan outcross. Woodford Mambrino started late in life, but got a record of $2.21 \frac{1}{2}$, and died before meeting the stud opportunity his breeding called for. $\mathrm{He}$ had same dam as Wedgewood, 2.19, the greatest compaigning stallion yet produced, and the only one to win all his races during the progress of a campaign through the Grand Circuit. Scutari was by a son of Mambrino Chief (his best son, so to speak), out of Sallina by Belmont, second dam, Susette by Pilot, Jt., third dam, Susan by American Eclipse, fourth dam by Woodpecker, fifth dam by Hephistion. He traces to Mambrino Chief twice, to Abdallah, 15, Pilot, Jr., Hambletonian, ro, and has a rich thoroughbred backing. $\mathrm{He}$ is in appearance a remarkably handsome horse, resembling Woodford Mambrino very much, it is said, by visitors having seen both horses. In action, pure-gaited, level-headed, and a fast stallion any time developed. As a sire, his colts speak louder in his behalf than words. He gets a line to that sire of game racehorses, Volunteer, and also to three noted broodmares, Woodbine, Belle and Martha.

As an outcross with blood of the Clay or Morgan families, he would meet his best success, and ought to produce a rare lot of performers. His daughters will stand inbreeding or will produce trotters to the cover of Wilkes horses. All in all, Scutari, JR., is a first-class individual. 


\title{
ALMONT EAGLE, 1054.
}

\author{
Record 2.27 .
}

Black stallion; foaled I 874 ; bred by Col. Richard West, Georgetown, Ky.; stands I 5.3 hands, and weighs I roo lbs.

[STANDARD, UNDER Rule 6.]

Sire, ALMONT, 33,

Record, $2.39 \frac{8}{4}$.

Sire of

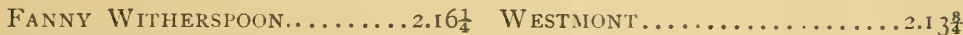

2-Inile record $4.46 \frac{1}{2}$.

Pienmont.................. 2.17 $\frac{1}{4}$

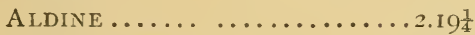

EARLY ROSE ..............2.20 $\frac{1}{4}$

Atlantic................2. I

First Dam, Mag Ferguson,

Dam of Piedmont, 2.17表 ( $\mathrm{I}$ in 2.30), Almont Eagle, 2.27, Mammont ( 2 in 2.30), and the dam of J. F. Phelps' $2.27 \frac{1}{4}$ dam.

Second Dam, Daughter of
Puritan...................... 16

Pacers.

Dams of

Alabaster (t years)........2.I5

C.ITCHFLY

by Mambrino Chief, i I,

Sire of Lady Thorn, 2.1 $8 \frac{1}{4}$, Woodford Nambrino, 2.2 I $\frac{1}{2}$, etc.; dams of Director, 2.17 , Piedmont, $2.17 \frac{1}{4}$, etc.

Sire also of Mambrino Patchen, the noted broodmare sire.

Grey Eagle,

Son of Woodpecker, by Bertrand, one of the best sons of Sir Archy, by Imp. Diomed. He was a creditable 4-mile race-horse in his days on the turf.

Almont Eagle is, in every way, a wonderfully well-bred stallion, and superlatively capable individually; Almont's dam being by Mambrino Chief, and from a Pilot, Jr., mare, and his dams are among Mambrino Chief's most successful producers. $\mathrm{He}$ is a much faster horse than his record indicates, and judges of experience stated, during his training, that he surely could beat 2.20 . Outside of Highland View his opportunities have been limited. 
We have here two which can trot in 2.25 to 2.20 , and several better than 2.30. They will be trained and placed in the list another season (189r); barring accidents will get fasts marks, and rank their sire among Almont's most productive speed-siring sons. His get are large, substantially fashioned, good-gaited, and handsome, uniformly; this, added to soundness and good dispositions, renders them very desirable for road use, where many have drifted after leaving their breeder's ownership. His sons breed a high class of colts, and from those among his daughters, which have been bred, we can show some remarkably promising speedy young animals. In every way Almont EAGLE is desirable to head any stud in America. His own brother, Piedmont, 2.1 $7 \frac{1}{4}$, is fast proving his value at Palo Alto, though overshadowed many years by the great Electioneer. At the close of r89 A Amont EAGLE will be found among the foremost of Almont's producing sons, and whoever secures him will secure one of the richest bred developed sires in America. He can beat his record easily many seconds with a month's track work; is roaded ten miles a day, and in the best condition for any use determined upon.

FOR SALE.

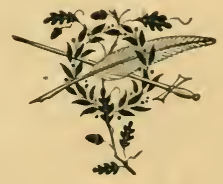




\section{IOLUNTEER BOY, 1612 .}

Trial, 2.27, Half in i.i3, Quarter in 35 Seconds.

Brother to Goldsmith's Abdallah, 2.30.

Dark bay stallion; foaled 1873 ; bred by Alden Goldsmith, Washingtonville, N. Y.

[Standard, Rule 6.]

Sire, VOLUNTEER, 55.

Sire of

ST. Julten.................. 2. I $\frac{1}{4}$

GLOSTER ....................2.17

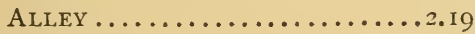

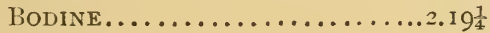

DrIVER .................

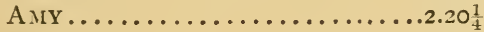

Domestic................2. $20 \frac{1}{2}$

etc.

First Dam, Martha,

Dam of Goldsmith Abdallah, 2.30 (4 in 2.30), John Bright (2 in 2.30 list and got dam of Betty Jones

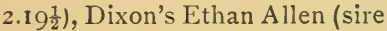
of Sensation, 2.22), Volunteer Boy (sired dam of Fearnaught, 2.19).

Second Dam, Daughter of

Third Dam, Daughter of

Fourth Dam, Daughter of
Sired dam of

Homestake................2.1 $4 \frac{1}{2}$

Amelia C................2.19

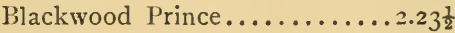

First Love.................2.22

Bon Bon ................2.26

and others. by ABDallah I.

Sire of O'Blemis, 2.27 , etc., the dams of Goldsmith Maid, 2.I4, and Harold, sire of Maud S.; also sire of Rysdyk's Hambletonian.

Bellfounder (Conklings'),

Son of Imp. Bellfounder.

CORNCRACKER,

Son of Imp. Tranby.

HiCKORY.

Volunteer Boy is a remarkably handsome bloodlike horse, and traces to the famous broodmare Lady Patriot (dam of Volunteer,

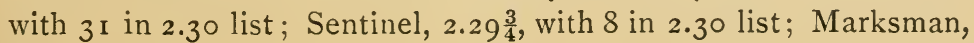


with 2 in 2.30 list; Green's Hambletonian, with I; and Heroine, dam of Shawmut, 2.26; and Martha on dam's side. He was a very fast horse himself, beautifully gaited, and went a mile in 2.27 ; could show a 2.20 gait, but met an accident which retired him. He has several which can beat 2.30 , but have trotted to save records, though his value as a sire is attested by Fearnaught, 2.I 9 (can trot in 2.17), which won fourth money at Hartford in the 2.20 $\$ 10,000$ race in 1890 , and nearly beat Prince Regent the fourth heat. We have several by him, very fast, and they will be brought out in $189 \mathrm{r}$. Hattie Proctor should be a great mare. The Volunteers are noted for gameness, soundness and longevity on turf or road, and the get of Volunteer Boy are not exceptions to the high grade gone before.

FOR SALE.

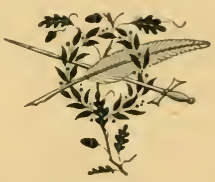




\section{VITT○RIA, 3993.}

[STANDARD, Rule 6.]

Brother in blood to Catchfly, 2.18 $\frac{1}{4}$.

Black stallion; foaled r88 r ; bred by Robert Steel, Philadelphia; stands 16 hands, full, and weighs I 50 lbs.

Sire, ADMINISTRATOR, 357.

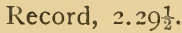

Sire of

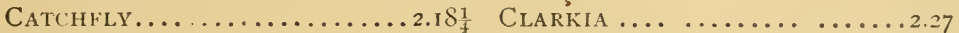

McMahon...............2.2 I Col. Stevens.............2.2 $8 \frac{1}{3}$

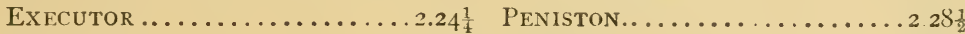

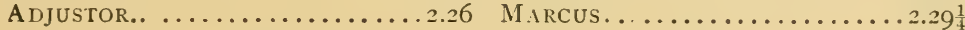

Arbiter....................... 30 .

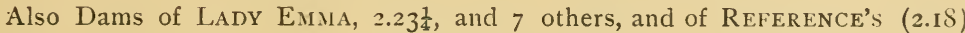
sire, REFEREE.

First Dam, Victorine,

Second Dam, Ama,

Third Dam, Miss Duncan,

Fourth Dam, Daughter of Bertrand, by Almont, 33,

Sire of 39 sons which have sired 120 , with records ranging from $2.12 \frac{8}{4}$ to 2.30 , and the dams of 27 in the 2.30 list.

by McDonald's Mambrino Chief,

Sire of dams of Alice West, 2.26, Stranger, 2.28 , and bred identical to Clark Chief, sire of dams of Phallas, 2.1 $3_{\frac{9}{4}}$, Majolica, 2.15, Wil-

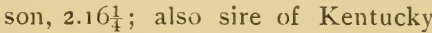
Prince, sire of Guy, 2.10? etc.

by Scotr's Highlander.

Son of Sir Archy. 
Fifth Dam, Daughter of

Sixth Dam, Daughter of
Aratus,

by Director, son of Sir Archy.

Timoleum,

Son of Sir Archy.

Sired Boston, he the sire of second dam of Maud S., 2.08是, Nutwood, 2.1 $8 \frac{8}{4}$, etc., etc.

Here is richness for you: Administrator, by Hambletonian, го, out of a Mambrino Chief mare; Almont, sire of his dam by Abdallah, I5, one of Hambletonian's best sons (opportunities considered the best), out of a mare by Mambrino Chief and Ama, Vittoria's second dam by a successful son of Mambrino Chief, the whole resting on a three-ply throughbred foundation, tracing each time through his most noted sons to Sir Archy, son of Diomed. Is it to be wondered at that VitToria gets fast colts, of great courage and determination, fine finished, and is, as well, a fast horse himself? No, it would be contrary to the laws of Nature were it otherwise. For an ideal broodmare sire he must be a grand success, and his daughters, when bred to Wilkes' Mambrino Patchen sires, are going to produce remarkably fast performers. The Hambletonian Mambrino blood stands doubling, and always improves when inbred through excellent individuals.

VITTORIA is probably the best bred son of his sire standing for service, if, indeed, not the best in existence. Administrator never was afforded the opportunity, but by downright meritorious individuality came into the front rank among sires, notwithstanding his obscurity. Several among VitTokin's get here are remarkably fast, and, when trained, will show very credifably.

FOR SALE.

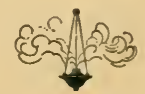




\section{GRANITE STATE, 6337.}

Dark bay stallion; foaled $\mathbf{1} 885$; bred at Highland View; stands I5.2 hands, and very handsome.

Sire, SCUTARI, JR.

.Son of Scutari, by Woodford Mambrino, $2.21 \frac{1}{2}$.

First Dam, Med ShePard,

by JACK SHEPARD,

Son of Hambletonian, Io, and sire of Minnie C., 2.25 $\frac{8}{\frac{8}{4}}$ etc.

Second Dam, Nashua,

A fast road mare.

Granite State adds to the Mambrino Hambletonian cross the blood of American Star through Laura Keene, dam of Jack Shepard. American Star mares were Hambletonian's best cross, and Hambletonian blood produced the Mambrino family's best performers, so in this blending we have intact all the proven speed fountains. He can show a very high rate of speed, though never trained.

FOR SALE. 


\section{NEWL ENGLAND.}

Black stallion; foaled 1887 ; bred at Highland View ; 16 hands full, and extremely handsome.

Sire, VITTORIA, son of ADMINISTRATOR, $2.29 \frac{1}{2}$.

Sire of Catchfly, 2.18 $\frac{1}{4}$, McMahon, 2.21 ( 2 in 2.30 list), and dam of LADY

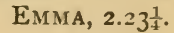

First Dam, Twistwood, Can beat 2.30 .

Third Dam, Hịbernia,

Fourth Dam, Daughter of

Fifth Dam, Roxanna, by BLACKWOOD, 2.3 I,

At 3 years,

Sire of Proteine, 2.18, Blackwood, Jr., $2.22 \frac{1}{2}$ (sire of Also, $2.20 \frac{1}{4}$ ), Black-

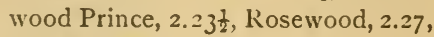
and Wildwood, 2.30.

Second Dam, Louise KellogG, by Dial.

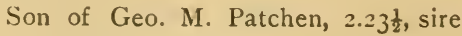
of Lucy, 2.1 $8 \frac{1}{4}$, etc.

by Imp. Consternation.

American Eclipse.

- By Duroc, hy Imp. Diomed.

by Sir ARCHY.

Son of Imp. Diomed, first Derby winner.

This is great breeding. Blackwood, 2.3 1 , could trot a 2.10 gait, and was out of a Mambrino Chief dam. Geo. M. Patchen, 2.23 $\frac{1}{2}$, led all the stallions of his time, and got Lucy, 2.18 $\frac{1}{4}$ (see Evolutio for her roll of honor), and leaving these we go through Imp. Consternation to Imp. Trustee, to American Eclipse, grandson of Diomed, back to Sir Archy, best son of Diomed. Vittoria adds Hambletonian and Mambrino Chief blood. $\mathrm{He}$ is the fastest trotter ever bred here, and a great-gaited, level-headed fellow. His dam is in the stud, but will be given a record before again being bred. She is one of Blackwood's speediest daughters, and a grand broodmare. NEw England, at any price, is a good in. vestment.

FOR SALE. 


\section{NEWL HATMPSHIRE.}

Seal brown stallion; foaled I886; bred at Highland View ; stands I 5.3 ; weighs ro75 lbs.

\section{Sire, VOLUNTEER BOY.}

Trial 2.27 .

Got dam of FEARNAUGHT, 2.19.

First Dam, Collie,

by Lakeland Abdallah, Brother to sire of Maud S., 2.0S亲, Queen of the Turf.

Second Dam, CARrie T., 2.34, Dam of Carrie Thomas, 3 years, 2.3 $\mathrm{I}$, and Bessie Wilkes, dam of Albrazia, 3 years, $2.31 \frac{1}{2}$.

Third Dam, Sister to MaUd,

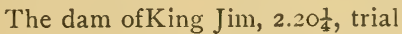
2.16, etc., and Malaga, dam of

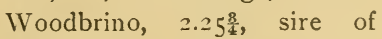
Cromwood, 2 years, 2.46 .

Fourth Dam, Daughter of

Fifth Dam, Daughter uF

Sixth Dam, Daughter of Seventh Dam, Daughter of by Almont, 33,

Sire of dam of Alabaster, 2.15; exchampion stallion at + years.

by AbDallah, I 5 ,

Sired dam of Jerome Eddy, $216 \frac{1}{2}$; sold for $\$ 25,000$.

Robert Bruce, By Clinton, son of Sir Archy.

MUCKLE JohN, By Sir Archy.

Trumpeter.

Stamboul (Arabian).

Highland View is bred much like New Hampshire, and the same treatise as to the bloodlines is applicable to each. NEw HAMPSHIRE is one of the fastest ones ever bred here, and very handsomely proportioned, upheaded and of speed-promise : showing it in his every move whilst in action. Sound and of a cheerful disposition, possessing a rare amount of nerve force. 


\section{VITTMTONT, 5998.}

Bay stallion; foaled 1886 ; bred at Highland View; stands $\mathbf{~} 6$ hands; weighs ro75 lbs.

\section{S!re, VITTORIA.}

Son of ADMINISTRATOR, $2.29 \frac{1}{2}$.

First Dam, Marjorie,

Second Dam, Belle,

Third Dam, Daughter of

Fourth Dam, Daughter of Brown Pilot,

Son of Pilot, the sire of Pilot, Jr., the greatest broodmare sire as far as extreme speed is concerned.

Vitmiont traces on each side to Almont, and each time through him to Abdallah, i5, and Mambrino Chief; also to Pilot, Jr. He gets a Clay outcross through one of the best of the descendants of Henry Clay, and it is well known that both Geo. Wilkes and Electioneer are by Hambletonian (sire of Administrator), out of Clay dams. He is inbred once remotely to Pilot, Jr.'s, sire, Pilot, a fast pacer, and of great individuality, judged by the contributions through his son's daughters to the 2.30 , and notably the 2.20 list. Through Cassius M. Clay, Jr., he goes to the Imp. Diomed sire, Duroc, through American Eclipse, his best son, and through Commodore twice to the founder of trotters in America, Imp. Messenger. $\mathrm{He}$ has, all told, 27 strains to Imp. Messenger, and 7 to Diomed, 4 to Mambrino Chief, II, 3 to Rysdyk's Hambletonian. A wonderfully rich pedigree, as a more minute analysis will at once establish. Every way he is a superlative young stallion, and of excellent finish, size, and can show a high rate of speed with great ease.

FOR SALE. 


\section{YOLTMONT, 5950.}

Blood bay; foaled 1885 ; bred at Highland View.

\section{Sire, VOLUNTEER BOY.}

Brother to Goldsmith's ABDALLAH, 2.30, etc.

First Dam, Marjorie,

Second Dam, Belle,

Third Dam, Daughter of

Fourth Dam, Daughter of by Almont, 33,

Sire of Fanny Witherspoon, 2.16立, Piedmont, $2.17 \frac{1}{4}$.

by Cass M. Clay, JR., 22.

Commodore (Hunt's).

- Brown Pilot,

Son of Pilot, sire of Pilot, Jr.

As Volunteer Boy and Marjorie are each catalogued, and have been discussed, it is unnecessary to enlarge on the breeding of VoLMONT. He is handsome, rangy, and elegantly gaitẹd; every way a promising stallion.

FOR SALE. 


\section{HIGHLAND VIEW, 7597.}

Mahogany bay stallion; foaled 1887 ; bred at Highland View ; stands 16 hands, and weighs r roo lbs.

Sire, VOLUNTEER BOY,

Trial 2.27.

First Dam, Faith Dudley,

Second Dam, Coliıe,

Third Dam, Carrie T.,

Record 2.34, Dam of Carrie Thomas, 3-year record 2.3 $\mathrm{I}$, also $2 \mathrm{~d}$ dam of Albrazia, 2-year record 2.32 $\frac{1}{2}, 3$-year record $2.31 \frac{1}{2}$.

Fourth Dam, Sister to Maud,

The dam of King Jim, $2.20 \frac{1}{2}$, and Malaga, dam of Woodbrino, $2.25 \frac{8}{4}$, also of Attorney, sire of Attorney,

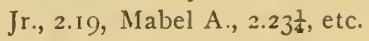

Fifth Dam, Daughter of

Sixth Dam, Daughter of

Seventh Dam, Daughter of Eighth Dam, Daughter of by Mambrino Dudley, 2.I $9 \frac{3}{4}$,

Sire of Crescendo, 2.24, trial 2.20, Gretna, $2.25 \frac{1}{4}$, Rintoul, $2.28 \frac{1}{2}$.

by LAKELAND ABDallah, Brother to Harold, sire of Maud S., etc.; sire of Geo. ()., 2.26, and dams of 2 in 2.30 list.

by Aliont, 33,

Sire of dams of Alabaster, 2.1 5, Catchfly, 2.18 $8 \frac{1}{4}$, McMahon, 2.21, etc., etc.

by ABDallah,

Sire of Goldsmith Maid, 2.14, and dams of Jerume Eddy, 2.16 $6 \frac{1}{4}$, etc.

Robert Bruce,

Son of Clinton, by Sir Archy.

MUCKLE JoHN, Son of Sir Archy.

Trumpeter.

Stamboul (Arabian).

This pedigree bristles with great broodmare strains, great sires as well, and has the greatest thoroughbred strains in existence to back it up: Martha, his maternal granddam, a producer both of 
speed and producing sons; Volunteer, dam, Lady Patriot, another wonderful matron, and on dam's side the great turf stars are near connections; Lakeland Abdallah, sire of his second dam, a brother to the sire of the fastest performer to date. Mam. Dudley never had a foal but that trotted or produced speed, and Sue Dudley has two in 2.30 list, and each have 2.30 performers already. His fourth dam was sister to the well-known Woodburn producer, Maud, a great mare. In addition to Abdallah, I5, Mambrino Chief, I r, and Volunteer, 55 (to Hambletonian), Highland View has a line to Edwin Forrest, sire of dam of Mambrino King, the sire of Prince Regent, 2.I $6 \frac{1}{2}$, Mocking Bird, 2.1 $6 \frac{3}{4}$, Henrietta, 2.1 $8 \frac{1}{4}$, and Jocko, pacer, 2.16 $\frac{1}{4}$. Every line goes into thoroughbred blood, and it will improve on examining into the breeders of the most famous performers bred that way, for the reason that identical strains are found among their direct ancestors. If breeding of this sort fails to produce a performer of merit, or a sire of speed, it will be a seldom found exception. He is one of the choicest, individually considered, stallions in New England, and fit to be placed in any stud collection in America.

FOR SALE.

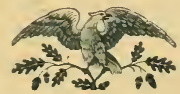




\section{ALMATE.}

Black stallion; foaled I886; bred at Highland View.

\section{Sire, ALMONT EAGLE, 2.27.}

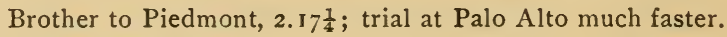

First Dam, Kitty Walker,

Second Dam, Daughter of

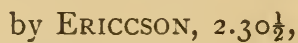

First to reach that mark as a 4 -year old, and sire of 6 in 2.30 , dams of $\mathrm{J}$. R.

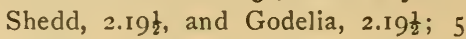
others.

Capt. Walker,

Sire of dams of Harry Wilkes, 2. I $3 \frac{1}{2}$, Charley, trial 2.158, and 3 others.

Here is another pedigree with a triple infusion of Mambrino Chief blood. There are, in addition, two out-crosses to pacing blood of productive merit.

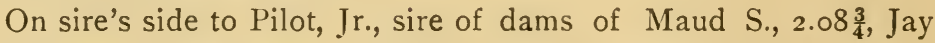
Eye See, 2.10, Nutwood, 2.18 $\frac{3}{4}$, etc., and through his dam-back to sire of Harry Wilkes' dam. He is not a large one, but very powerfully made from head to heels, and no inclination to mix or amble. His trotting action is beautiful and he may go very fast if

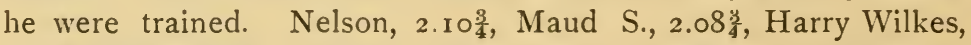
2.1 $3 \frac{1}{2}$, Manzanita, 2.16, and others, are in a measure indebted to the pacing brood for their speed. Almate's pacing strains are those identical ones which have best resulted when introduced into trotting pedigrees heretofore. He will sire speed beyond a shadow of doubt, and is one of the nicest roadster stallions ever foaled.

\section{FOR SALE.}

Note. - Indian Hill Farm has a yearling out of a daughter of Kitty Walker's, sired by the young stallion, Indian Hill, by Princeps, which they term the fastest colt ever foaled there, and the list of record trotters bred there includes Trinket, 2.14, Epaulet, 2.19, and others, consequently the compliment is a great credit to Kitty Walker as a speed progenitor. The dam of this colt is in foal to Axtel, 2.12; service fee, \$I,000. 


\section{BROODMARES.}

\section{COLLIE.}

[Standard, Rule 6.]

Mahogany bay mare; foaled 1878 ; bred by H. B. Tully, Russelville, Ky.; stands 16 hands full, and very handsome.

\section{Sire, LAKELAND ABDALLAH, 351.}

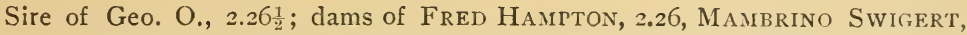
2.30. Own brother to Harold, the sire of Maud S., 2.08 $\frac{3}{4}$, etc.

First Dam, CARrie T., 2.34,

Dam of Maggie Thomas, $2.3 \mathrm{t}$ at 3 years, also of Bessie Wilkes, dam of Albrazia, 2.3 $\frac{1}{2}$ (3).

Second Dam, Sister to MaUd,

Dam of King Jim, 2.201 trial 2.15

Third Dam, Daughter of

Fourth Dam, Daughter of

Fifth Dam, Daughter of Sixth Dam, Daughter of by Almont, 33,

Sire of 39 sons with 125 in $2.30 ; 20$ daughters with 24 in 2.30 list.

by Abdallah, I5,

Sire of Almont, Belmont, Thornedale, Jim Munroe, etc., all with performers in the 2.30 list.

Robert Bruce,

Son of Clinton, by Sir Archy.

Muckle John,

By Sir Archy.

TRUMPETER.

Stamboul (Arabian).

Collie is a magnificent rangy bloodlike mare, an excellent producer, and her foals inherit her fine size and elegant appearance. They show speed and testify in every department as to the dam's qualifications for broodmare use. She is one of the finest bred mares in the land, as a careful analysis of her pedigree will show. Lakeland Abdallah with proper opportunities afforded him would have been a wonderfully successful sire. He was early taken to a locality more interested in breeding draught than trotting lines. 


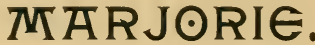

\author{
[Standard, Rule 6.]
}

Dark bay; foaled 1874 ; bred by Dr. Samuel H. Chew, Lexington, Ky.; stands 16 hands; very handsome.

Sire, ALMONT, 33.

Sire of

Fanny Witherspoon, $2.16 \frac{1}{4}$; Pienmont, $2.17 \frac{1}{1} ;$ Aldine, 2 I $9 \frac{1}{4}$; Westmont, 2.13; Puritan, 2.16, and others; and dam of Alabaster, record at 4 years 2.I 5 , 3 d heat.

First Dam, BeLle,

by Strader's Cass. M. Clay, Jr.

Sire of 8 sons with $\mathbf{1} S$ in 2.30 list; 12 daughters with 13 in 2.30 list; record $2.35 \frac{1}{4}$.

Second Dam, Daughter of Commodore (Hunt's).

Third Dam, Daughter of Brown Pilot,

By Pilot, founder of the Pilot, Jr., family.

MARJORIE is one of Almont's best bred daughters, and highly prized at Highland View; Volmont, out of her, is a fast young - horse. Dr. Chew, her breeder, considered her one of the most finished and elegant mares in Kentucky, as was her dam, the Commodore mare. She produces invariably a fine type of beauty; from suckling form to maturity they never lose their marked symmetry of proportion. MARJORIE will produce speed at Highland View, and we expect a rare foal when we mate her with Evolutio. 


\section{TWISTWLOD.}

[STANDARD, RULE 6.]

Brown mare, almost black; foaled 1879 ; bred by G. W. Homer, West Newton, Mass; stands 15.2 hands, and extra rangy.

\section{Sire, BLACKWOOD.}

3-year record $2.3 \mathrm{I}$.

Sire of

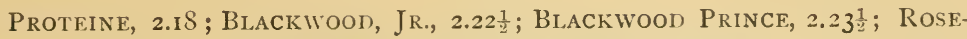
wood, 2.27, etc.; and dam of Merry Thought, $2.22 \frac{1}{2}$, etc.; one of the speediest stallions ever foaled.

First Dam, Louise KellogG,

by DiaL,

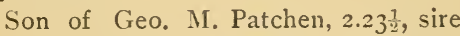
of the noted producer and performer, Lucy, 2.1 $\frac{1}{2}$, and Godfrey's Patchen, he sire of Hopeful, $2.14 \frac{8}{4}$.

Second Dam, Daughter of Third Dam, Daughter of

Fourth Dam, Roxanna,
Imp. Consternation.

American Eclipse.

Famous racehorse.

by Sir ArChy.

Twistwoon traces twice to Imp. Trustee, the great 20-mile trotter, and is a mare remarkable for her beautiful finish, intelligence and high nerve force. She can trot in or near 2.30 , and is very nervy but well behaved. At twenty she will be as graceful as she is now. Her sire, Blackwood, could go quarters in 32 seconds as a threeyear old, and sold for $\$ 25,000$. He yet lives at an advanced age, sound as a dollar and rugged. The Blackwoods are a speedy, dead game, long-lived lot of trotters, and campaign successfully. They are so highly organized that it becomes necessary to be very gentle in training them, though not "rattle-headed" necessarily. When bred they are a grand lot of producers. That the blood breeds on Blackwood, Jr., $2.22 \frac{1}{2}$, has shown in his table of performers, having 5 in 2.30 and dam of another already. Daughters of Blackwood have produced Merry Thought, $2.22 \frac{1}{2}$, and several others. Twistwoon's foals here will bear very critical examination, and all show her elegance, and show speed as well of a high order. 


\title{
ALMAW○OD.
}

\author{
[STANDARD, Rule 6.]
}

Black without white; foaled I886; bred at Highland View.

Sire, ALMONT EAGLE, 2.27.

First Dam, Twistwood,

by Blåckwood, $2.3 \mathrm{I}$,

Out of a Mambrino Chief dam.

Second Dam, Louise Kellogg, by Dial,

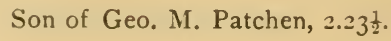

Third Dam, Daughter of

Fourth Dam, Roxanna,

Fifth Dam, Roxanna,
Imp. Consternation.

by American Eclipse,

by Duroc, son of Diomed, noted 3 - and 4-mile racehorse.

by SIR ARCHY,

Best son of Diomed.

Here we have a richly constructed pedigree, replete in its Mambrino Chief dams, and with a line each to the famous 4-mile racehorses, Grey Eagle and American Eclipse. Her Abdallah, I 5, blood never met better crosses than this combination furnish. Not a strain to a faint-hearted family, and with a Clay outcross as well as one to Alexander's Norman, a family which claims Lula, 2. I5, May Queen, 2.20, dams of Norman Medium, 2.20, Norval, 2.1 $7 \frac{1}{2}$ (sire of Norlain, r-year record 2.3 $1 \frac{3}{4}$ ), and nine more. Almawood is well qualified to pass down to her produce a high rate of. speed. She inherits it, and better still possesses it individually, is a beautiful, sound, stylish young mare. We shall probably train her pre-" vious to permanently retiring her from the stud. She has no "slack places" and those who have looked her over are loud in her praises. What a colt she will produce bred to Evolutio. 


\section{CRYSTAL.}

[STANDARI BREI).]

Dark chestnut; foaled I 883 ; bred by Highland View.

Sire, ROBT. BURNS.

Son of Winthrop Morrill, dam Highland QueEn, by Rysdyk's HaMbleTONIAN.

First Dam, Fanny Lambert, by Daniel Lambert, Io2,

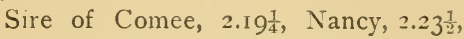
Ella Doe, $2.23 \frac{1}{2}$, and 32 others; also dams of Pamlico, 2.16 $\frac{3}{4}$, Dandy Jim, 2.I $9 \frac{1}{2}$, Revenue, $2.22 \frac{1}{4}$, and 16 others.

Second Dam,

Grey Mare,

Claimed to be a Messenger.

CRYSTAL is in conformation a beautiful mare, strongly imbued with the Lambert characteristics ; can trot very fast, and with opportunity should very nearly trot in 2.20 to prophecy within bounds.

\section{ROSE WLOD.}

[STANDARD.]

Bay mare; foaled 1885 ; bred by Highland View.

Sire, SCUTARI, JR.

First Dam, Twistwood,

by BLACKWOOD, 2.3 I.

Second Dam, Louise KellogG, by Dial,

Son of Geo. M. Patchen, 2.23․․

Third Dam, Hibernia, by Imp. Consternation.

Fourth Dam, Roxanna, by Ainerican Eclipse.

Fifth Dam, Roxanna, by Sir ARCHY.

Examine ScUtaRI, JR.'s bloodlines, then turn to Twistwood and weigh well the breeding values of this pedigree for broodmare's use. Individually she comes up to the standard of excellence it calls for, is nicely gaited, and should she be handled would undoubtedly trot fast. Her every movement is grace itself. 


\section{COLLEEN.}

[StANDARD, RULE 6.]

Brownish chestnut; foaled 1887 ; bred by John F. Mills, Boston, Mass.

Sire, ABBOTTONIAN.

Son of Mambrino Dudley, 2.19⿺辶一

First Dam, Crystal,

Second Dam, Daughter of by ROBERT Burns,

Son of Winthrop Morrill.

DANiel LAMBert, IO2,

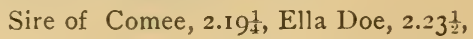
etc.

Abbottonian's dam, Muse, was by Winthrop Morrill, out of the well known trotting mare Lady Thornton, $2.26 \frac{1}{2}$ (dam of Virginia Evans, 2.24, trial 2.18), and has sired some very promising foals. Robert Burns' dam was by Old Hambletonian, 2 d dam by Thos. Jefferson, son of Mambrino Paymaster, Jr., 3d dam, a daughter of Mambrino Paymaster. Thos. Jefferson's dam was also by Mam. Paymaster, giving three direct strains to Mambrino Paymaster, sire of Mambrino Chief, II, the great sire of Lady Thorne, 2.1 $8 \frac{1}{4}$.

\section{CHRIST ABEL.}

[Standard, Rule 6.]

Black filly; no white; foaled I $888^{\circ}$; bred at Highland View.

Sire, ALMONT EAGLE, 2.27.

First Dam, Crystal,

bY ROBERT BURNS.

Second Dam, Fanny Lambert, by Daniel Lambert.

The Mambrino Chief blood, technically speaking, is the background for this pedigree. Robert Burns traces three times to Mambrino Chief's sire, and Almont Eagle twice to Mambrino Chief himself. Daniel Lambert throws in a strong dash of the best Morgan, backed by Abdallah and American Star strains. She is a very excellently well-bred filly, and can trot quite a bit, though it is, of course, all natural speed, for she has not had a moment's handling. 


\section{EARLY DAWN.}

[STANDARI, REGISTERED.]

Bay mare ; foaled 1885 ; bred by R. S. Bent, Natick, Mass.

Sire, KENTUCKY WILKES, 1854.

Record $2.21 \frac{1}{2}$.

Sire of

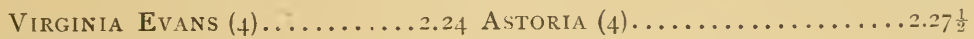

First Dam, Duette, _ by Princeps, 5.36,

Son of Woodford Mambrino, out of daughter of Abdallah, I5, sire of

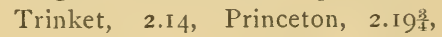

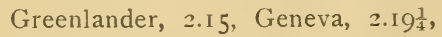

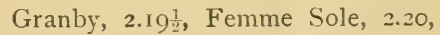
and 15 others in 2.20, dams of Epaulet, 2.19, and 7 others in 2.30 .

Second Dam, Belle Dudley, by Beliont, 64,

Dam of Prince Dudley, 2.29:3, at 2 years; public trial $2.22 \frac{3}{4}$, at 3 years; also of Dodd Peet, pacing record, 3 years, $2.19 \frac{1}{2}$.

Trial 2.28 $\frac{1}{4}$,

Sire of Fred Arthur, 2.1 $3 \frac{8}{9}$, Nutwood, 2.I 8 , Wedgewood, 2.19, Viking, $2.19 \frac{1}{4}$, etc., etc.

Third Dam, Madale Dudley, Breeding not established.

Dam of By a Bashaw Horse.

SuE DudLEy, which produced Mambrino Dudley, 2.19 $\frac{8}{4}(3$ in 2.30 list), Grosjean, 2.30 ( $\mathrm{I}$ in 2.30 list), Sacramento (sire of Nellie Rose, $2.25 \frac{1}{4}$ ).

DAHLIA, dam of Daireen, $2.2 \mathrm{I} \frac{1}{4}$, trial 2.18, Dacia, 2.29: (dam of Daciana,

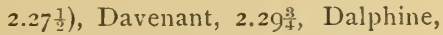

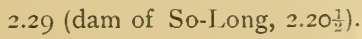

Tulip, dam of Ulva, 2.27 (public trial $\left.2.22 \frac{8}{4}\right)$.

Belle Dudley, dam of Dodd Peet, 2. $19 \frac{1}{2}$, Belford, 2.26\%, Prince Dudley, $2.29 \frac{3}{4}$.

DALCE, dam of Greenhorn, $2.2 S \frac{1}{4}$. 
No mare living has a greater array of producing ancestors than EARly Dawn. Her sire, by Geo. Wilkes, out of Minna, by Red Jacket, which produced the dam of Lizzie Wilkes, $2.22 \frac{3}{4}$; her dam by Princeps; he by the great sire Woodford Mambrino, $2.2 \mathrm{I} \frac{1}{2}$, which was out of dam of Wedgewood, 2.19; Princeps, dam by Abdallah, 15 ; second dam, Black Rose, by Tom Teemer; Prim. rose, dam of Redwald, $2.28 \frac{1}{2}$, etc.; Black Rose, dam of Hermosa,

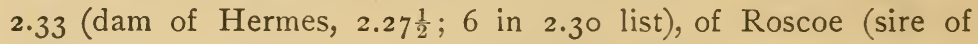

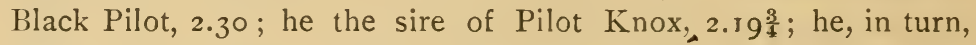
sire of Pilot Bird, 2.22 $\frac{3}{4}$ ). Black Rose is dam of the dams of Hermes, Heptagon, Abdalbrino, Maxion, Parmenus, Princeps, Pluto, which have totally produced 40 in 2.30 list. Primrose produced

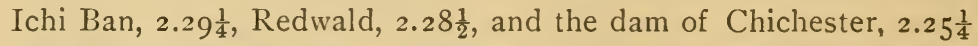
(sire of Stornaway, 2.30). Belmont brings in a producing dam as well. Every line to a producing dam, and, as endeavored to illustrate the best and most positive "breeding on blood" in all the stud-book. She is a beautifully-gaited, fast, and handsome young mare, and worth, in these days of advanced breeding, $\$$ ro, 000 , to be mated with any sire of prominence. How can she miss being a great producer herself.

\section{LOREEN.}

[STANDARD, RULE 6.]

Bay mare; no white; bred by Cornelius O'Neill, Mystic Park, Medford, Mass; foaled I 886.

\section{Sire JERSEY WILKES, 5916.}

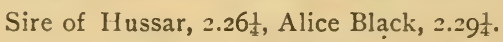

First Dam, Lady Messenger, by Messenger Chief, i 825 ,

Sire of Maud Messenger, 2.161, Katherine S., 2.20 $\frac{1}{2}$, Abel, $2.24 \frac{1}{4}$. etc.; dam of Messenger Wilkes, $2.29 \frac{8}{1 .}$.

Second Dam, Daughter of

WhALEBONe, Son of Mambrino Chief, $\mathbf{I}$.

Third Dam, Daughter of Frank,

Son of Sir Archy. 
Jersey Wilkes, sired by Geo. Wilkes, dam Lady Patchen (dam of Jimmie Temple, $223 \frac{1}{2}$ ), by Mambrino Patchen, traces to the best thoroughbred blood: Messenger Chief, sired by Abdallah Pilot, he out of Blandina (the dam of five sires), by Mambrino Chief; second dam, Burch mare, dam of Rosalind, 2.2 I $\frac{3}{4}$; his dam was by Mambrino Messenger, by Mambrino Chief, and second dam by Mambrino Chief is dam of Gen. Geo. H. Thomas, 2.30, sire of Annie H., 2.20, Scott's Thomas, 2.2 I, etc., a famous Tennessee sire. We have Wilkes Mambrino Patchen, the golden strains backed with several direct lines to Mambrino Chief, twice to the blood of the greatest son of Imp. Diomed, Sir Archy.

Loreen is in foal to Rex Nutwood, a commingling of the Abdallah, r5, Pilot, Jr., Mam. Chief and thoroughbred; all to strictly high-class sires and dams as well.

\section{MAUD A.}

[Standari, Rule 6.]

Bay mare ; foaled 1884 ; bred by Wm. Abbott, Boston, Mass.

Sire, WEDGEWOOD, 2.19, 692.

Sire of

Favonia..................... 5

ConWAY...................

Connaught...............2.24

MYrTLEWOOD $\ldots \ldots \ldots \ldots \ldots .2 .25^{\frac{1}{4}}$

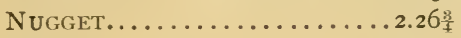

Ulva $\ldots \ldots \ldots \ldots \ldots \ldots \ldots .2 .27$

First Dam, Muse,

Second Dam, Lady Thornton, by Mapes Horse.

$$
2.26 \frac{1}{2}
$$

Third Dam, Daughter of

Fourth Dam, Wildair MARE.

Crescendo $\ldots . . \ldots \ldots \ldots \ldots \ldots .2 .24$

Holmdel, 3 years.............2.29 $\frac{1}{1}$

Clenmore ..................2.29

Braxdoline...............2. $30 \frac{1}{2}$

by Winthrop Morrill.

EDSALL'S JUPITER. Son of Jupiter, 46.

Here we get performers and producers closely related. Wedgewood won all his races through the Grand Circuit in I880, a feat never before or since accomplished by any horse, mare or gelding. $\mathrm{He}$ is breeding on in every direction, and Nugget, besides having a list to his credit, has already a son which is credited with $2.3^{\circ}$ performers. 


\title{
MARGUERITE.
}

[STANDARD, Rule 6.]

Bay mare; foaled 1888 ; bred at Highland View.

Sire VITTORIA, 3993.

First Dam, MARJORY,

Second Dam, Belie,

Third Dam, Daughter of

Fourth Dam, Daughtér of by Almont, 33 .

Son of Abdallah, 15 .

by C. M. Clay, 22

(Strader's).

Hunt's Commodore.

Brown Pilot,

by Pilot, sire of Pilot, Jr., I 2.

Marguerite is full sister to Vittmont, and same remarks as to breeding qualifications, of excellence, etc., is equally applicable to each. She will be bred to "Evolutio" in 1891.

\section{MARGARET.}

\author{
[STANDARD.]
}

Black mare; foaled 1886 ; bred at Highland View.

\section{Sire ALMONT EAGLE, 2.27.}

Brother to Piedmont, sire of dam of Lizziemont, $2.25 \frac{1}{4}$, and FAnNy IVILCox, $2.29 \frac{1}{2}$; first among Jerome Eddy's get to beat 2.30.

First Dam, Mary Curtis,

Second Dam, Daughter of

Elijah Hoffman mare. by Volunteer Bơy.

Trial, 2.27.

Black Sherman, 240.

Traces direct to Hill's Black Hawk and Bellfounder.

This breeding is elegant so far as it extends, and composed of animals excellent individually. She is a fine young mare and half sister to Scutari, Jr., one of our best young stallions; a trotter of promise and will be a good producer. Individually she compares with any on the farm. 


\section{ELFIN.}

[STANDARD BRED.]

Dark bay; foaled $\mathrm{r}_{5} 8_{5}$; bred by us at Highland View.

\section{Sire VOLUNTEER BOY.}

Trial 2.27 .

First Dam, FAnNy,

by FLORIDA, 482,

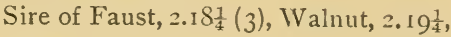

Fanny Swope, 2.21, Fortuna (3),

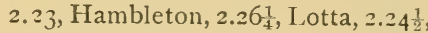

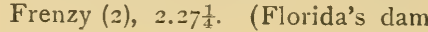

by Volunteer, 55.)

Second Dam, Daughter of Dad, 2.40,

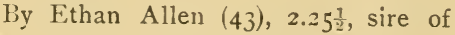

Daniel Lambert, I02, etc., etc.

ELFIN calls for more than passing notice. She is inbred to the great Volunteer, the founder of the gamest, nerviest family of campaigners ever started, and she goes back to the sire of the greatest Morgan (Daniel Lambert) ever foaled, which had few opportunities but overcame all obstacles, and contributed 39 trotters and dams of 24 more to the list.

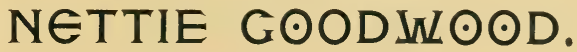

[STANDARD, RULe 6.]

Chestnut mare, I5.2 ; foaled 188 I ; bred by John F. Merrow, Esq., Revere House, Boston, Mass.

\section{Sire, GOODWOOD.}

Son of WOOIFORd MaMirino, $2.2 \mathrm{I} \frac{1}{2}$.

First Dam, Nettie Burlew, Record, 2.24.

Much faster than her mark, and could go halves in 1.06. A very speedy mare. by CHAMPION, 807 (King's), Sire of Nettie Burlew, 2.24, Geo. B. Daniels, 2.24, Charley B., 2.25 , Myrtle, 2.25 $2.25 \frac{1}{4}$, Col. Barnes, $2.28 \frac{1}{2}$, News. boy, 2.27 , Sorrell Dapper, 2.28 $\frac{1}{2}$; dams of Frank Middleton, $2.20 \frac{8}{4}$, and 5 others in 2.30 . 
Second Dam, Nipper,

Great road mare, fast for her draught; was never trained. by Geo. M. Patchen, 30, 2.23 $\frac{1}{2}$,

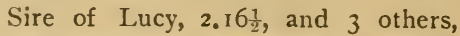
and dams of 6 others in the 2.30 list.

Netrie Goodwood is a grand mare, and her yearling by Vittoria, good judges say, could show better than a three-minute gait, loose in the paddock, and strong, pure gait. He at once makes a reputation for NetTiE, for, bar all accident, it will be a very easy task for him to trot in 2.30 at 3 -years'-old form. The 'mare is very nicely bred in true and tried lines, traces direct to the famous Geo. M. Patchen, king of the turf during his years, and gets through the Champion's the blood of Almack. Nettie Burlew was a terribly speedy mare, and could doubtess trot a quarter at a 2.08 gait. She frequently went halves at a 2.12 gait in her work. She inherits speed and can trot quite fast untrained, but is needed at Highland View for broodmare use. That she will be very valuable as a producer, we think none who ever saw her or her produce will for a moment question.

\section{TMISS WLESTON}

Brown mare; foaled 1887 ; bred by Geo. A. Weston, Bellows Falls, Vt.

\section{Sire, VITTORIA, 3993.}

First Dam, Rosa,

Great road mare.

Second Dam, The Ransom Bur-

$$
\text { DITT MARE, }
$$

Owned at Pittsford, Vt., passed to

Ransom Davis of Saxton's River,

Vt. Produced Arabian Girl, 2.40

(dam of Psyche, $2.27 \frac{1}{4}$ ), also the

dam of Spotted Jim, 2.33. Six

of her produce could beat 2.30

had they been handled. by CARÑAC,

Son of Ashland, he sire of danis of

Edw. Thorne, 2.161, Black Cloud, $2.17 \frac{1}{4}$, etc.

by Churchill Horse, Son of Black Hawk, 5 .

There is marked individuality combined with breeding in the case of Miss Weston. She will be a good producer we firmly believe. 


\section{NAIAD.}

[STANTARD, RULE 6.]

Bay mare ; foaled I 882 ; bred by Col. H. S. Russell, Milton, Mass. Sire, SMUGGLER, $2.15 \frac{1}{1}$.

Champion Stallion from 1875 to $188_{3}$.

Sire of

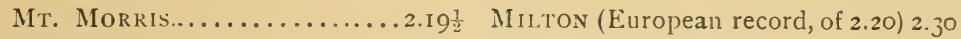

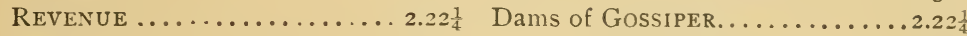

Siruggle...................24

SMUGGLER'S DAUGHTER $\quad \ldots .2 .24 \frac{3}{4}$

Young SMUGGLER............2.29妾

First Dam, Sea Foan, $2.24 \frac{1}{2}$, by Young Columbus,

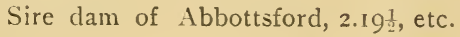

Second Dam, The Jos. H. Bil-

$$
\text { LINGS MARE. }
$$

A great roader and quite fast.

This is breeding which has already trotted and acquired fast records. Smuggler mares are producing speed very uniformly. NAIAD is bred to Evolutio, adding another fastest on record to the breeding.

\section{HARTELLE.}

[STANDARD, RULE 6.]

Bay mare; foaled 1885 ; bred by S. IV. Parlin, Phillips, Me.

Sire, ALMONT EAGLE, 2.27.

First Dam, Heartless,

by HARTFORD,

Son of Rysdyk, sire of Clingstone, 2.14 .

Second Dam, DaM OF Jersey

$$
\text { Lily, by Telegraph, }
$$

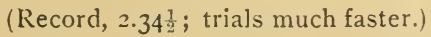

Son of Locomotive, by Blucher.

Third Dam, Daughter of

Charlton Horse.

Could trot very fast, and drew weight as well. 
This is a great young mare. Her foal here by Allectus (son of Alcantara), Quintuple, can show, loose, as much speed as any we ever saw at same age, and individually is a beauty. She is bred in well-tried lines. Hartford was out of Belle, said to be by Hambletonian, ro, but registered once as by that horse himself, again as by "a Hambletonian horse." Rysdyk was out of Lady Duke, by Lexington, granddam by Medoc. Jersey Lily could trot in $\mathbf{2 . 2 5}$, but was bred before entering the list.

HARTELLE is herself beautifully gaited, a nice finished mare and finely coated winter or summer. She must produce a fine line of foals judged by the first one, Quintuple.

\section{MTERTM AID.}

Trial, 2.28.

[STANDARI, RUle 6.]

Dark bay mare; foaled I882; bred by John F. Merrow, Revere House, Boston, Mass.

Sire, VOLUNTEER BOY.

Trial, 2.27 .

First Dam, SEA FoAM,

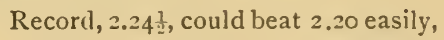
and won 24 hotly contested heats.

Second Dan, Daughter of

The Billings Mare, owned by Col.

H. S. Russell.

MERMAID is one of the big broodmares, standing 16 hands and over. A magnificent, roomy, high finished one all over, and by a successful son of Volunteer, sire of the gamest family of trotting horses extant, and out of a fast daughter of the nervy, game, Columbus, a similar, though improved (through her sire) strain to that which produced Phyllis, 2.I $5 \frac{1}{2}$, one of the greatest 
performers; a mare which began as a two-year old and trained many years, going into a faster class each season, and could beat $2.15 \frac{1}{2}$.

Mermaid can enter the list still. She is so well fortified with speed-producers that it is preferable to breed her each season. She will be mated with Evolutio, and we hope for something great. It will be an outcross, and a good one as well.

\section{CLARETMONT TMAID.}

[STANDARd, Rule 6.]

Brown mare; foaled I 884 ; bred by Joshua Wilkins, Braintree, Mass.

Sire, ARBITER 2.30, 991.

By Administrator, 2.29 $\frac{1}{2}$, Dam Alma Mater, by Mambrino Patchen, 5 , dam of Alcantara, Alcyone and Allicia.

First Dam, Media,

Second Dam, Daughter of

Third Dam, Daughter of by Garrard Chief, 2253

(Son of Mambrino Chief). Was sire of Basil Duke, $2.28 \frac{1}{4}$, and dams of Don Pizarro (3), 2,14色, Mistake, $2.29 \frac{1}{2}$.

Abdallah Messenger, 8or, (Son of Abdallah, $\mathrm{I}_{5}$,) sire of Abdal.

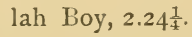

St. Lawrence Horse.

Said to be.

Claremont Maid traces direct to Mambrino Chief three times, and once indirectly to Abdallah, I5, and Administrator, both successful sons of "The Old Hero of Chester," and must make a grand broodmare. Mares by sons of Alma Mater are now commanding high prices, and not obtainable at that, as well bred on dam's side as is Claremont Maid. She is just what we are using at Highland View in our stud for broodmare use, and intend to retain her fillies to add also to our collection. 


\section{ALTARI.}

[STANDARd, Rule 6.]

Brown mare; foaled r886; bred at Highland View.

Sire, SCUTARI, JR.

First Dam, Daughter of

Second Dam, Sired BY
Aliont EAGLe, 2.27.

Sire of Ruby Almont, trial, $2.28 \frac{1}{4}$.

Son of Vt. Black Hawk,

Which was inbred to the Morgan strains.

This filly we have kept for broodmare use. She has plenty of rich bloodlines through her sire, her grandsire and the sire of her dam, and it is backed by an inbred Morgan foundation of great value even in these days of advanced breeding, as Bell Hamlin, 2. I $2 \frac{3}{4}$, Guy, 2.1 $\frac{3}{4}$, Pamlico, 2.16 $\frac{3}{4}$, and others going back to Black Hawk testified in public. The Morgan element produces finish, substance and courage, together with road-horse qualities of high order.

\section{REXIE LATMBERT.}

[STANDARD.]

Grey mare; foaled I879; bred by Geo. W. Gould, Newtonville, Mass.

Sire, REX PATCHEN, 2.30.

Sire of REX, 2.2S1

First Dam, Fanny Lambert,

Second Dam, Daughter of by Daniel Lambert, i 02 ,

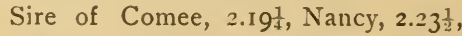

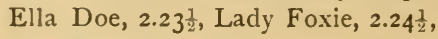
and many others.

Young EngineER.

Said to be.

Rexie Lambert is a nice daughter of a fast daughter of the great sire, Daniel Lambert, by far the greatest native New England sire. Her foal, Clay Patchen, stamps her a grand producer. She has a brother which would have beaten 2.30 had he had training. 


\section{BROWN FERN.}

[Standard, Rule 6.]

Brown mare; foaled 1885 ; bred at Highland View.

Sire, SCUTARI, JR.

Son of Scutari, by Woodford Mambrino, $2.21 \frac{1}{2}$.

First Dam, Fernleaf,

Second Dam, Daughter of by IDOL, I77,

Son of Mambrino Chief, $\mathbf{I}$, dam by American Eclipse, by Duroc, son of Diomed.

VT. Black Hawk, 5,

Sire of Ethan Allen, 2.25 $\frac{1}{2}$.

We get here a great blending of Mambrino Chief blood with that of Abdallah, r5, then Belmont and to Hambletonian, 10, through Volunteer, together with the ever-valued Morgan element, through the great old-time sire, Black Hawk. She gets a stout dash of best thoroughbred blood right close up.

\section{RED FERN.}

[STANDARD, Rule 6.]

Bay; no marks; 15.2 hands; foaled 1885 ; bred at Highland View.

\section{Sire, VOLUNTEER BOY.}

Got dam of Fearnaught, 2.I9.

First Dam, Ferndell,

by IDOL, I 77 ,

Son of Mambrino Chief, II, and sire

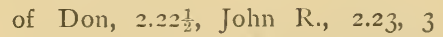
others: dams of Misty Morning, $2.2 \mathrm{I}$, etc.

Second Dam, Daughter of

Black Hawk, 5 ,

Sire of Ethan Allen, 2.25 $\frac{1}{2}$.

Peck's Idol was by Mambrino Chief, dam by American Eclipse, the great racehorse; American Eclipse, by Duroc, son of Diomed, out of Miller's Damsel, by Imp. Messenger. RED FERN is well qualified for broodmare use. 


\section{VIOLA WLILKES.}

[STANDARD, RUle 6.]

Grey mare; foaled 1885 ; bred by Dr. F. L. Gerald, Laconia, N. H. Sire, MAMBRINO WILKES, 3880, 2.28辛.

Sire of

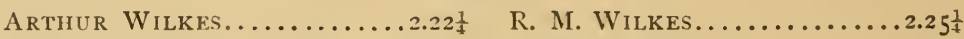

Dam Viola,

by Administrator, 357, $2.29 \frac{1}{2}$,

Sire of Catchfly, 2.1 $8 \frac{1}{4}$, McMahon, $2.21 \frac{1}{4}$, etc., etc.

Second Dam, Valley Rose,

by PECK'S IDOL, I77,

Son of Mambrino Chief.

Third Dam, TARGET,

by Sir WALlace.

Fourth Dam, Daughter of Kosciusko,

by Sir Archy.

Fifth Dam, Daughter of Blackburn's Whip.

MAMBRino Wilkes,

First Dam, Hatite Fitch,

Second Dam, Lady Turner,

Dam of Ned, dam of Clemmie G.,

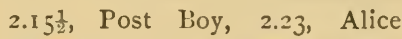

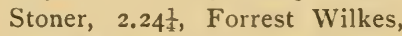

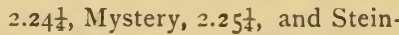
ette, dam of Bourbon Russell, 2.30.

Third Dam, Daughter of

Fourth Dam, Daughter of

Fifth Dam, Daughter of

Sixth Dam, Daughter of by Geo. Wilkes, 2.22, 5 19, Sire of 70 in 2.30 list.

by William's Mambrino, Son of Ericcson by Mambrino Chief. by Mambrino Chief.

Grey Eagle.

Sir Wm. Wallace.

BLACKBURN'S Whip.

Conet.

Peck's Idol by Mambrino Chief, dam by American Eclipse, son of Duroc, by Diomed. American Eclipse, dam Miller's Damsel by Imp. Messenger.

Kosciusko, by Sir Archy.

Sir Archy, by Diomed, first English Derby Winner, dam by Rockingham. 
Viola Wilkes is exceptionally well bred, and inheriting, as she does, the blood of the famous Mrs. Caudle, dam of Ericcson, and of Lady Turner, dam of the grand producer, Ned, with five in the list, and a sixth, a producer of one, we think her well qualified to transmit her speed inheritance. She can show quite a deal of natural speed with a splendid way of handling herself loose in the lot. She strains four times to Mambrino Chief and twice to Hambletonian, ro, once through his very best son, Geo. Wilkes, once through a most excellent son, opportunity considered, Administrator, whose daughters are passing 2.30 speed into the list each season. With her breeding excellence and individual excellence we look for good results from her union with the Highland View stallions.

\section{MEDORA.}

Bay mare; foaled r 886 ; bred at Highland View.

\section{Sire, VOLUNTEER BOY.}

First Dam, Med Shepard,

by JaCk Shepard, I 83 ,

Son of Hambletonian, ro, out of an

Second Dam, Nashua.

\section{American Star Dam.}

Great roadmare.

A great individual; very promising.

\section{LADY BATES.}

Gray mare; foaled 1877 ; bred by Estate of B. E. Bates, Cream Hill Farm, Shoreham, Vt.

Sire, ABRAHAM, 353.

Sire of

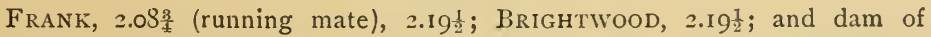
$\mathrm{KETCH}, 2.18$ 妾.

Dam, Hartshorne Mare, Messenger Descent.

Said to be. 


\section{QUEEN DIDO.}

[STANDARD.]

Dark bay; 15.3 hands; foaled, 1887 ; bred by Jas. Piper, Claremont, N. H.

Sire, VITTORIA, 3993.

First Dam, Daughter of. Second Dam, Daughter uf
Aliont Eagle, 2.27 .

Metcalf HoRse.

By Black Hawk, 5 .

\section{MISS CARROLL.}

Bay mare; foaled, 1885 ; bred by N. C. Carroll, Warner, N. H. Sire, VOLUNTEER BOY, 2.27.

First Dam, Daughter of ABDallah, I6,

Sire of Minnie C., 2.25年, etc.

\section{TATMAR.}

Bay mare; foaled 1887 ; bred by Bert Chellis, Claremont, N. H. Sire, VOLUNTEER BOY.

Trial 2.27 .

First Dam, Daughter of

ROBERT BURNS,

Son of Winthrop Morill, out of Highland Queen, by Hambletonian, 10.

In foal to Eagle Wilkes.

\section{QUEEN ELIZABETH.}

[STANDARD.]

Bay; no white; foaled 1887 ; bred at Highland View.

Sire, ALMONT EAGLE, 2.27.

First Dam, Mary Curtis, by Volunteer Boy.

Trial 2.27.

Second Dam, Daughter of Elijah Hoffman Mare.
Black Sherman, 2.40, Out of a Bellfounder mare. 


\section{EUDORA.}

Brown mare ; foaled 1882 ; bred by Mr. Fitch, Claremont, N. H.

\section{Sire, ALMONT EAGLE, 2.27.}

Brother to Piedmont, 2.17 $\frac{1}{4}$, etc.

Dam, Daughter of

Second Dam, Daughter of

Third Dam, Daughter of
Young Draco,

Son of Draco, 2.2 $\$ \frac{1}{2}$, sire of Draco Prince, $2.24 \frac{1}{2}$, Blanche, $2.25 \frac{1}{4}$, Outlaw, 2.281; also dam of Young Rolfe, sire of Nelson, 2.10 氶.

Cole Horse,

By the Perry Horse, son of Vermont Black Hawk.

Bell Morgan, 6i,

Sire of Lady Turpin, 2.23 (by Cottrell Morgan, son of Black Hawk).

EUDORA is a grand roadmare; can trot right round 2.40 , and is speedy, handsome, nice-gaited, and able to give one a good stiff cross-country ride of forty miles, and return, without being at all fatigued, yet doesn't pull a pound. Her breeding is very good a double Morgan foundation and the Abdallah Mambrino Chief top-cross. Statistics show that the old-time Morgan blood mingles with the more fashionable strains in the veins of Nelson, 2.1033, Axtell, 2.12, and a number of others among the bright stars either before the public, on the turf, or in the stud.

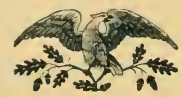




\section{YEARLINGS.}

EASTER.

[StANDARD, Rule 6.]

Bay filly; foaled Easter Sunday, I889; bred by A. Cunio, Boston.

\section{Sire, NELSON, 2.10욘.}

The Stallion King, holder of the three best records possessed by any stallion. living or dead:-

2. $5 \frac{1}{4}$, fastest one-half mile track record by any horse, mare or gelding.

2. I I $\frac{8}{4}$, fastest stallion record over a kite-shaped track.

2. $10 \frac{9}{4}$, fastest stallion record on any track made on regulation-shaped track.

2.I $5 \frac{1}{2}-2.15 \frac{1}{4}$, fastest consecutive heats over half-mile track.

First Dam, Norma,

Second Dam, Alnorma,

Third Dam, Daughter of by Happy Medium, 400,

Sire of Maxey Cobb, 2.I $3 \frac{1}{4}$, ex-champion stallion record; Maxey Cobb and Neta Medium, 2.15是, till IS90 fastest double team record; Nancy Hanks, 4 years old, 2.14 $\frac{1}{4}$, fastest race record at the age, fastest third heat at 4 years old; and 50 others in 230 ; also dams of 12 others.

by Almont, 33,

Sire of dams of Alabaster, 2.15, second fastest 4-year stallion record made as well in a race, Catchfly. 2. $18 \frac{1}{4}$, etc.

Norman, 25 ,

Sire of Lila, 2.I $<\frac{8}{4}$, May Queen, 2.20, dam of Norval, 2.17 $\frac{1}{2}$, Norman Medium, 2.20 , etc. 
Nelson, 2.10 $/ 4$...

Champion Stallion. Record, $2.15^{1 / 4}$, over a half mile track.

Fastest on Rंecord.

\section{Norma}

Young Rolfe, 2.211/4 Sire of

Nelson . . . . 2.10 24 Aubine . . . . 2.19

Medora . . . . 2.22 $32^{3 / 4}$ Prescnt . . . 2. 2.23t/2

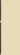

Gretchen .... \{

Dam of

Nelson .... 2, $\mathrm{10}^{3 / 4}$

Susic Owen ...2.26

Knox Girl . . 2.2.31

$$
\text { Dam of }
$$

Aubine . . . 2. 2.19 $1 / 4$ Medora... . . 2.223\%

Westland ... . 2.31

\section{Happy Medium, 400.} Sire of

Maxey Cobb . . 2, $13^{1 / 4}$ Norman Medium 2.20 Buzz Medium . 2.201/4 Brigadier ... 2.21 $1 \%$ Breeze Medium . 2.2. $1 /$ Ernest Maltravers $2.22 \mathrm{1} / \mathrm{s}$ First Love . . 2.2.21/ Happy Thought . $2.221 / 2$ Merry Thought $\cdot 2.22^{1}$ Neta Medium . 2.22 $1 / 2$

Alnorma . . . . .

Aratus, by

DIRECTOR .

Sir ARCHY.

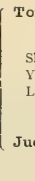

$$
\text { Sire of }
$$

Sleepy Torn . . 2.12 $2^{1}$ z

Young Rolfe ...2.2.11/4

Lady Rolfe, . . 2.2 $t^{1 / 2}$

Judith...... \{

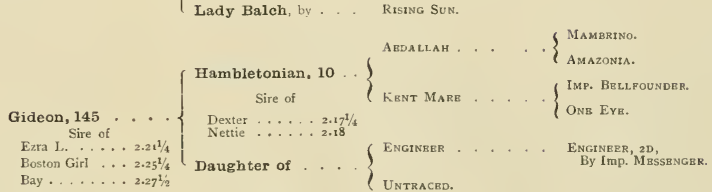

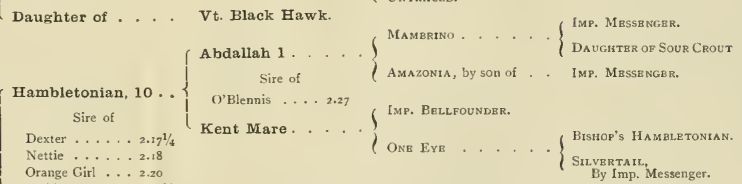

Orange Girl $\ldots 2=0$

Artillery . . 2.2.2 $1 / 4$

Princess, 2.30 ...

Hambletonian
(Andrus) $\cdots\left\{\begin{array}{c}\text { Hambletontan, by } \\ \text { (Judson's). } \\ \text { Untraced. }\end{array}\right.$

Sire of

Princess $\ldots \ldots 2.30$ Engineer, by . . ENGINRER, 20,

Wilcox Mare. . . $\left\{\begin{array}{rr}\text { ENGINEER, by } & \text { ENGINRER, } 20, \\ \text { (Burdick's) } & \text { By Imp. Messenger. }\end{array}\right.$

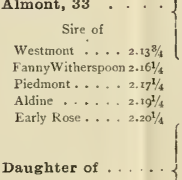

Abdallah, 15... $\left\{\right.$ Hambeztonian, ro. . $\left\{\begin{array}{l}\text { A gonllah, t. } \\ \text { Kent Marb. }\end{array}\right.$

Sire of

Goldsmith Maid . 2.14 (MAM. PAymaster.

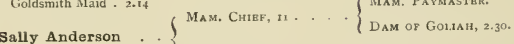

( POPE Mare, by ... PILOT, Jk.
EURopban.

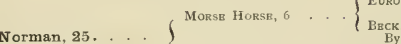

Sire of

Lulu ...... 2.14

Untraced. 

EASTER is designed as a broodmare; was purchased especially to mate at reaching her third year with my young stallion, "Evolutio," getting in the prospective foal the blood of all the great sires, Nutwood, Alcantara, Geo. Wilkes, Young Rolfe, Happy Medium, Almont, Alexander, Norman, and the famous broodmares, Miss Russell, Lucy, Gretchen, Alma Mater, and the great performers, Nelson, 2.1 $\circ \frac{3}{4}$, Goldsmith Maid, 2.14, Lady Thorne, 2.18 $\frac{1}{4}$, Lucy, 2.1 $8 \frac{1}{4}$, Geo. Wilkes, 2.22, Alcantara, 2.23, Jay Gould, 2.20 $\frac{1}{2}$, Young

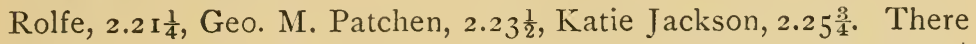
will be no greater bred one to have been foaled than the issue of EAster by Evolutio. She is not for sale, money won't buy her, and individually she is a perfect young mare, which we value only second as a breeding requisite to sound ancestry.

\section{OAKLOOD.}

[STANDARD.]

Sire, VITTORIA, 3993.

Bay colt; foaled 1889 ; bred at Highland View.

Dam, Nettie Goodwood,

by Goodwood,

Son of Woodford Mambrino, $2.21 \frac{1}{2}$.

Second Dam, Nettie Burlew, by Champion, 807 (King's). 2.24 .

Third Dam, NIPPER.

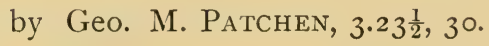

OAKWOOD is the fastest colt of his age we ever had here. He can show more speed and more stride in the yards than termed average speed limit for unbroken yearling form, and must, with no accident or set back, become a very fast horse. His action is perfect and he is a very large colt for the age. Horsemen who have seen him, all pronounce him a wonderfully-gaited colt, and -a very promising one for turf honors at maturity. 


\section{EBONY.}

Black colt; foaled I 889 ; bred by Highland View.

Sire, VITTORIA, 3993.

Dam, Daughter of

Second Dam, Daughter of
Almont Eagle, 2.27 .

Abe Rogers,

By Vt. Black Hawk, 5 .

This colt is fine and handsome; an own brother to Bellrice, our gelding of 1888 .

\section{PICCOLO.}

Cherry bay gelding; foaled r889; bred by Mr. Piper, Claremont. Sire, VITTMONT.

Dam, Piper Mare,

Second Dam, Daughter of by ScUtari, JR.

SON OF Black Hawk, 5.

This is a nice, pretty colt, beautifully colored, and wears a coat like silk; he is stylishly gaited.

\section{ATMBER.}

Roan colt; foaled $\mathrm{r} 889$; bred at Highland View.

Sire, VITTORIA, 3993.

Dam, Lady Bates,

by Abraham,

Son of Daniel Lambert.

\section{SILK BOY.}

[STANDARD, Rule 6.]

Brownish bay; foaled 1889 ; bred at Highland View.

Sire, SCUTARI, JR.

Sire of SCUTARI by WOODFORD MAMBrino, $2.21 \frac{1}{2}$.

Dam, Almawood,

by Almont Eagle, 2.27,

Sire of Ruby Almont; trial $2.28 \frac{1}{4}$. 
Second Dam, Twistwood,

by BlackWOOD, 2.3 I,

Sire of Protein, 2.1S.

Third Dam, Louise Kellogg, by Dial,

Son of Geo. M. Patchen, 30, sire of Lucy, 2.I $\$ \frac{1}{4}$.

Fourth Dam, Hibernia, by Imp. CONSTERnation.

Fifth Dam, Roxanna, by AMERICAN ECLIPSE.

By Duroc, by Diomed.

Sixth Dam, Roxanna, by SiR ARCHY,

Best Son of Imp. Diomed.

This is grand breeding, and better even than good breeding; Silk Boy is absolutely perfect at every point. Evenly balanced in his every movement, and a trotter from heels up. He is unusually handsome, of good size, and beautifully coated. We have determined to keep him a stallion, thinking he will be quite up to our standard of excellence.

\section{HOLLYWOOD.}

[STANDARD, RUle. 6.]

Chestnut filly; foaled r 889 ; bred at Highland View.

Sire, GRANITE STATE, 6337.

Dam, Rexie LAMBERT,

by Rex Patchen, 2.30, 9i2.

Sire of Rex, 2.2S $\frac{1}{2}$.

Second Dam, Fanny Lambert, by Daniel Lambert, io2, Sire of Comee, $2.19 \frac{1}{4}$, etc.

Third Dam, Daughter of Young Engineer.

Claimed to be. 


\section{IDYLLWLOOD.}

[STANDARD, Rule 6.]

Bay filly; foaled I889; bred at Highland View.

Sire, VITTORIA, 3993.

Dam, REDFERN,

Second Dam, FernleaF, by Volunteer Boy.

by Peck's IdoL,

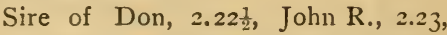

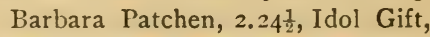
$2.29 \frac{1}{2}$, Iodine, $2.29 \frac{1}{2}$, dams of 6 in 2. 30 list.

\section{LOUELLA C.}

[STANDARD, RULE 6.]

Bay filly; foaled I889; bred by Edward Cogswell, Hyde Park, Mass.

Sire, NORTHCOTE.

Son of Mambrino Russell, he by Woodford Mambrino out of Miss RUSSELL.

First Dam, Jennie Patchen, Dam of Arrago, 2.33․․

Second Dam, Jennie,

Third Dam, Daughter of by Tом Patchen, 3996,

Sire of Captain, 2.2 $1 \frac{1}{2}$, Jack Spratt, 2.23, Gladiator, Jr., $2.27 \frac{1}{2}$, and grand.

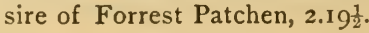

by Gen. Knox, 140, 2.3 I $\frac{1}{2}$,

Sire of Lady Maud, 2.18 $\frac{1}{4}$, etc.

Drew Horse, I I 4,

Sire of dams of Midnight, 2.I $8 \frac{1}{4}$, Iron Age, 2, $19 \frac{1}{4}$, and others.

This breeding is excellent. Mam. Russell's dam, by Volunteer, is a sister to Stephen G., $2.20 \frac{1}{2}$, second dam being by Knickerbocker, and produced Stephen G. Mambrino Russell sired Hal- 
dane, Happy Russell, Allie Russell and others, and was out of

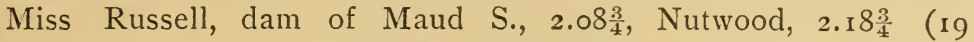
in 1890 in the list), Cora Belmont, $2.24 \frac{1}{4}$, Russia, 2.28, and Nutula, dam of Maudlin, Lord Russell, sire of Kremlin, 2.22 $\frac{3}{4}$, at 3 years old. We get the great broodmares, Miss Russell, Lady Patriot, Woodbine, a mighty trio, and of invaluable speed productive influence. Everything which was produced by each has either trotted or produced performers, and their performers are great campaigners and hold the low down records. Gen. Knox, with limited opportunities, did wonderful service to the trotting interests of Maine, and established a family which, whether possessed of 2.30 speed or slower, "all trot some." No one ever saw a Knox which couldn't show some sort of speedy inclination. The Patchen blood and Drew are valued outcrosses. Louella C. is a very promising filly and will be a great broodmare. Will be bred to Rex Nutwood, doubling the Miss Russell blood in the produce.

\section{NIXIE.}

Bay filly; foaled 1889 ; bred at Highland View.

Sire, VITTORIA, 3993.

Dam Miss Carroll, by Volunteer Boy. Trial, 2.27.

Second Dam, Daughter of AbDallah, i6 (Taggart's).

\section{CHELLISSA.}

Bay filly; foaled r889; bred by Burt Chellis, Claremont, N. H. Sire, VOLUNTEER BOY. Trial, 2.27 .

Dam JenNy,

Second dam, Daughter of by Gen. LYun, Son of Young Morrill.

PATHFinder.

Morrill Horse. 


\section{SAT ANELLA.}

[STANDARD, Rule 6.]

Bay filly; foaled 1889 ; bred at Highland View.

Sire, VOLUNTEER BOY.

Trial, 2.27 .

First Dam, Maud A.,

Second Dam, Muse,

Third Dam, Lady Thornton, by Mapes Horse, 2063.

$$
2.26 \frac{1}{4}
$$

Dam of Virginia Evans.

Fourth Dam, DAughter of

Fifth Dam,
bY WEDGEWOOD, 2.19, 600 .

by Winthrop MORRILL, 373 .

Comment on this breeding would seem well nigh superfluous. It is replete with strains directly to successful sires, and the dams all round were all producers of attested value. She is a smartgaited miss, and we expect her to show well when thoroughly broken. In conformation she is about perfect, and much admired by those who have seen her.

\section{MOLLIE WILKES.}

[Standari, RUle 7.]

Black brown filly; foaled r889; bred at Highland View.

\section{Sire, EAGLE WILKES.}

Dam, Mary Curtis,

Second Dam, Daughter of by Volunteer Boy.

Trial 2.27.

Black Sherman, By Vermont Black Hawk, 5. 


\section{MARGOT.}

Bay filly; foaled 1889 ; bred by Highland View.

Sire, CLAY ABDALLAH.

Dam, Marjory,

by Almont, 33,

Sire of dam of Alabaster, 2.15, at 4 years.

Second Dam, Belle,

by Cass. M. Clay, JR., 22

(Strader's).

Record $2.35^{\frac{1}{4}}$.

Third Dam, Daughter of Hunt's Commodore.

Fourth Dam, Daughter of . Brown Pilot,

He by Pilot, sire of Pilot, Jr., I2.

We have here an indirectly inbred Clay, with a Hambletonian outcross, and it makes quite an interesting pedigree. A reference to the breeding of Clay Abdallah will be of interest.

\section{KATHLEEN.}

[STANISARD, RULF, 6.]

Black filly; foaled 1889 ; bred at Highland View.

Sire, EAGLE WILKES.

Dam, Collie,

by Lakeland AbDallah, Brother to Sire of Maud S.

Second Dam, Carrie T., 2.34, by Almont, 33,

Dam of Maggie Thomas, 2.3r ; second Sire of dam of Alabaster, + years, 2.15. dam of Albrazia, 2.3r $\frac{1}{2}$ ( 3 years). 
Third Dam, Maud's Sister,

Fourth Dam, Daughter of

Fifth Dam, Daughter of

Sixth Dam, Daughter of

Seventh Dam, I)AUGGHER OF by Abdallah, I 5 ,

Sire of The Maid, 2.14.

ROBERT BRUCE,

Son of Clinton, by Sir Archy.

Muckle John,

By Sir Archy.

TRUMPETER.

Stamboul (Arabian).

EAGLE Wilkes is considered as handsome as the great show horse, Mambrino King, by some, and is certainly a very handsome horse under any judging. KATHLEEN compares in point of breeding favorably with almost any her age. She has the Wilkes, Almont, Abdallah, I5, and best of thoroughbred backing, tracing three times direct to Sir Archy; and on the sire's side three great 4-mile runners are represented: Grey Eagle, Wagner, and Lexingington. Individually we are confident she will meet the approval of those her rare breeding may attract. From any standpoint she is a superior young filly, and after we trial her at maturity she will go into the stud, where she must needs be a grand producer.

\section{MONTCLAIR.}

Seal brown colt ; foaled 1889 ; bred at Highland View.

Sire, VOLMONT, 5950.

First Dam, Claremont Maid, by Arbiter, 2.30,

By Administrator, out of Alma Mater, dam of Alcantara, 2.23, Alcyone, 2.27, Allicia, 2.30, Arbiter, 2.30.

Second Dam, Media,

by Garrard Chief, 2253

(Son of Mambrino Chief). Was sire

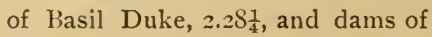
Don Pizarro (3), 2.14星, Mistake, $2.29 \frac{1}{2}$. 
Third Dam, Daughter of

Fourth Dam, Daughter of
Abdallah Messenger, 8or.

St. Lawrence Horse.

Said to be.

Here we get Volunteer, Almont, Mambrino Chief, Mambrino Patchen, and thoroughbred foundation, a grandly bred (grandly constructed as well) individual.

\section{REGRET.}

\section{[STANDARD, RULE 6.]}

Black filly; foaled I889; bred at Highland View.

Sire, VITTMONT, 5998.

Dam, Rosewood,

Second Dam, Twistwood,

Third Dam, Louise KellogG,

Fourth Dam, Hibernia,

Fifth Dam, Roxanna,

Sixth Dam, Roxanna, by Scutari, Jr.

by BlaCKWOOD, 2.3 I.

by DIAL,

Son of Geo. M. Patchen, $2.23 \frac{1}{2}$.

By Imp. Consternation.

by AMERICAN ECLIPSE.

by SIR ARCHY,

Son of Imp. Diomed.

This filly is one of the finest bred ones to be found, look where one may. No better trotting strains exist, and the broodmares in existence with such influential strains as Consternation, Eclipse, and Sir Archy, together with the Trustee blood, render it almost beyond comparison, unless one be bred in identical lines. Very clean cut, and a pretty gaited little miss already. 


\section{COLT FOALS, 1890.}

NETTLE.

Bay; foaled r89o; bred at Highland View.

- Sire, GRANITE STATE.

Dam, Nettie Goodwood, Dam of Oakwood. by Goodwood,

Son of Woodford Mambrino, 2.21 $\frac{1}{2}$.

Second Dam, Nettie Burlew, by Champion, 807,

$$
2.24 \text {. }
$$

Third Dam, NıPPER,

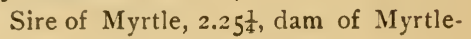

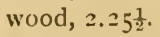

by Geo. M. Patchen, $2.23 \frac{1}{2}$,

Sire of Lucy, $2.18 \frac{1}{4}$.

This colt is half brother to Oakwood, the fastest yearling ever raised here, and is a grand gaited youngster already. He may be almost as fast same age as his half brother was.

\section{VICTOR CURTIS.}

\section{[STANDARD.]}

Brownish bay; foaled 1890 ; bred at Highland View.

Sire, VITTMONT, 5950.

First Dam, Mary Curtis,

by Volunteer Boy.

Dam of Scutari, Jr.

Second Dam, Eljua Hoffman

$$
\text { MARE. }
$$

Black Sherman's Dai, by Black Sherman, Son of Vt. Black Hawk:

The Hainill Mare, By Imp. Bellfounder.

VICTOR CURTIS is a grand colt as to breeding, viewed in the light of an outcross, as he has the valued Morgan outcross for a foundation, improved by the infusion of the blood of Volunteer, Almont and Administrator. 


\section{SATINWOOD.}

[StANDARD, Rule 6.]

Bay colt; foaled I 890 ; bred at Highland View

\section{Sire, REX NUTWOOD.}

First Dam, Rosewood,

Second Dam, Twistwood,

Third Dam, Louise KellogG,

Fourth Dam, Hibernia,

Fifth Dam, Roxanna,

Sixth Dam, Roxanna, by SCUTARI, JR.

by BLACKWOOD, 231 .

by Dial.

-by Imp. Consternation.

by AMERICAN ECLIPSE.

by Sir ARCHY.

$\mathrm{He}$ is a grandly bred colt, replete with producing strains of rare merit and great brilliancy. $\mathrm{He}$ is as fine in form and finish as one could imagine and a very pleasing colt. He at once stamps his sire a good producer, and his dam is one of our highly prized young broodmares. SATINwOOD is good sized for his age, and will be a fine yearling.

\section{MTEDINA.}

[Standard, Rule 6.]

Dark bay; foaled I89o; bred at Highland View.

Sire, EAGLE WILKES.

Dam Medora, by Volunteer Boy. Trial, 2.27.

Second Dam, Med Shepard, by JACK Shepard, $\mathrm{r}_{3}$, Sire of four with records, $2.25 \frac{1}{4}$ to $2.29 \frac{1}{4}$. 
Third Dam, Nashua.

A noted long distance roadmare, with considerable local reputation for speed possession.

Medina is a large, well made, good-looking colt, elegantly colored, and will, without any unforseen accident, become a very promising young horse. $\mathrm{He}$ is very nervy, stylish as a young peacock, and comes naturally by it all; his sire and his dam's sire both are elegantly finished stallions.

\section{PEERLESS.}

[STANDARD, RULE 6.]

Bay colt ; foaled 1890; bred at Highland View.

Sire, VOLMONT, 5950.

First Dam, Early Dawn,

Second Dam, Duette,

Third Dam, Belle Dudley,

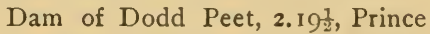

Dudley, 2.29冬 (2), Belford, 2.26量.

Fourth Dam, Madam Dudley,

Dam of four producing daughters. by Kentucky Wilkes, 2.2 I $\frac{1}{2}$,

Sire of Virginia Evans, 2.24 (trial, 2.IS).

by Princeps,

Sire of Trinkett, 2.I4.

by Belmont, 64,

Sire of Nutwood, 2.18 8 .

A Bashaw.

Said to be.

When we interweave the blood of Almont, Geo. Wilkes, Woodford Mambrino, Abdallah, I5, Mambrino Chief, Belmont, Volunteer, Cass. M. Clay, Jr., and the best background of thoroughbred sires in the Stud Book near at hand, it ought to be termed giltedged. When the strains were begotten by the highest representative sires in these families it is advancing, as they are many times 
much better bred than are their sires. Add to all this the great producers, Belle Dudley, Mme. Dudley, Primrose, Woodbine, Belle, Martha, Lady Patriot, and there is hereditary excellence on every limb of the tree. Peerless ought to be a successful sire, a fast trotter, and yet is but a yearling as yet. Few colts are as well qualified for the stud as he, and whatever families may be fashionable a few years away, we think the "boom" will still be "on" in his families.

\title{
INFUSION.
}

\author{
[Standard, Rule 6.]
}

Black colt ; foaled 1890 ; bred at Highland View.

\section{Sire, EAGLE WILKES.}

First Dam, Elfin,

by Volunteer Bor,

Trial, $2.27 \frac{1}{4}$, brother to Goldsmith's Abdallah, 2.30, and sire of dam of Fearnaught, 2.19.

Second Dam, FAnNy,

by FLORIDA, 482,

Sire of Faust, 2.1 $1 \frac{1}{4}(3)$, Walnut

2.19 $\frac{1}{4}$, Fanny Swope, 2.2 I, Fortuna,

2.23, Hambletonian, 2.2611, Lotta, $2.24 \frac{1}{2}$, Frenzy (2), $2.27 \frac{1}{4}$.

Third. Dam, Daughter of

DAD, 2.40,

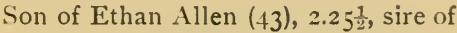
Daniel Lambert, I02, etc., etc.

This breeding is essentially gilt-edged, the individuality is there, and in every respect he is first class on examination. 


\section{CLAY PATCHEN.}

Black colt ; foaled I890; bred at Highland View.

Sire, CLAY ABDALLAH.

Dam, Rexie Lambert, by Rex Patchen, 2.30.

Second Dam, Fanny Lambert, by Daniel Lamber $\mathrm{r}$, I02,

Sire of dams of Pamlico, 2.16

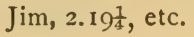

Third Dam, Daughter of Young Engineer.

This is a very handsome colt and well bred as well. Clay Abdallah's breeding will at once impress the reader as exceptionally valued for an outcross. He can step quite a lively gait for a yearling unbroken. 


\section{FILLY FOALS.}

\section{VISTA.}

[STANDARD, RULE 6.]

Bay filly; foaled 1890 ; bred at Highland View.

Sire, REX NUTWOOD.

Son of Nutwood, 2.183. Put 19 in 2.30 list during 1890.

Dam, Maud A.,

Second Dam, Muse,

Third Dam, Lady Thornton,

$$
2.26 \frac{1}{2}
$$

Dam of Virginia Evans, 2.24 ; trial, 2.18.

Fourth Dam, Daughter of, Edsall's Jupiter.

Fifth Dam, Wildair Mare, by Wildair.

\section{SOLITAIRE.}

[STANDARD, Rule 6.]

Bay filly; foaled I 890 ; bred at Highland View.

Sire, WM. H. MOODY.

Dam, Collie,

by Lakeland Abdallah,

Brother to sire of Maud S., 2.08s.

Second Dam, Carrie T., 2.34, by Almont, 33.

Dam of Maggie Thomas, 3 years,

"The great sire of trotters." 2.3I ; Bessie Wilkes, dam of Albrazia, $2.3 \mathrm{~T} \frac{1}{2}$. 
Third Dam, Sister to Maud,

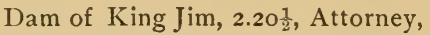
sire of Attorney, Jr., 2.I3, Mabel A., 2.23, Malaga, dam of Woodbrino, $2.25 \frac{3}{4}$.

Fourth Dam, Daughter of

Fifth Dam, Daughter of

Sixth Dam, Daughter of

Seventh Dam, Daughter of by ABDALlah, I 5 ,

Sire of Goldsmith Maid, 2.14, etc.

RoBT. BROWN, By Clinton, son of Sir Archy.

Muckle John, By Sir Archy.

TRUMPETER.

Stamboul (Arabian).

Wm. H. Moody, by Vittoria, son of Administrator, dam Mer-

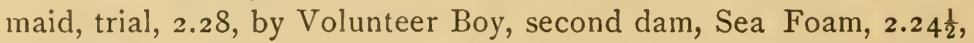
introduces a double cross of Mambrino Chief blood, the valued Abdallah, I5, blood, and that of the great sire of campaigners, Volunteer, 55. On dam's side Solitaire gets more Mambrino Chief-Abdallah, I 5 (twice), with a phenomenal thoroughbred backing. She is the first of her young sire's get, and is a very creditable tribute. It would be hard to exact a more perfect head and neck than she carries, and from end to end there seems no flaw in her make-up. Every one who has seen her has commented on her rare finish and beautifully colored, sleekly-laid coat. She knows nothing but trot, and for a weanling is extra attractive in action, and shows quite a deal of juvenile speed, loose in the yards.

\section{REYERIE.}

[STANDARD.]

Bay filly; foaled I 890 ; bred at Highland View.

\section{Sire, EAGLE WILKES.}

Dam, Red Fern,

Second Dam, Ferndell, by Volunteer Boy.

by PECK's IDOL,

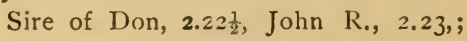
3 others. 
Third Dam, Daughter of

VT. Black HaWK, 5,

Sire of Ethan Allen, 2.25 $5^{\frac{1}{2}}$.

This filly combines the blood-lines sired to Geo. Wilkes, Almont, Alexander's Abdallah, Mambrino Chief, Pilot, Jr., and thoroughbred, backed by the Black Hawk strain, famous for constitutional vigor, beauty of finish, and a very valuable outcross for any animal to possess.

\section{COMBINATION.}

[STANDARD.]

Brown filly; foaled I 890 ; bred by Highland View.

Sire, EASTERN BOY, $2.29 \frac{1}{2}$.

First Dam, NAIAD,

by Simugler, 2.1 $5 \frac{1}{4}$.

Stallion King, $1875-{ }^{-I} S_{3}$.

Second Dam, Sea Foam, $2.24 \frac{1}{4}$, by Young Columbus.

Third Dam, Billings Mare.

Wonderful road-mare, very fast, and

a great long distance animal.

Owned by Col. Russell.

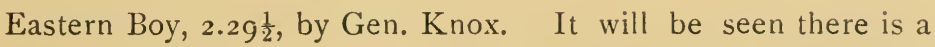
line everywhere to some developed speed ancestor. Sea Foam was a much faster mare than her record indicates. Gen. Knox, $2.3 \mathrm{I} \frac{1}{2}$, made a great reputation under extremely adverse circumstances. 


\section{VIOLET.}

[STANDARD, RULE 6.]

Dark bay filly; foaled I89o; bred at Highland View.

Sire, VITTMONT.

Dam, Miss Carroli, by Volunteer Boy.

Second Dam, Daughter of Abdallah, I6 (Taggart's).

\section{HAУEN.}

Bay filly; foaled $\mathbf{1} 890$; bred by C. A. Haven, Claremont, N. H. Sire, VOLUNTEER BOY.

Trial, 2.27.

Dam, Daughter of

ROBERT BURNS,

By Winthrop Morrill, out of Highland Queen, by Hambletonian, Io. 


\section{ROXIE.}

[STANDARD, Rule 6.]

Bay filly; foaled 1890 ; bred at Highland View.

Sire, REX NUTWOOD.

Dam, Altari,

Second Dam, Daughter of

Third Dam, Daughter of by ScUTARI, JR.

Almont Eagle, 2.27.

Son of Black HaWk, 5 .

This filly proclaims her young sire a getter of juvenile promise, and is a very elegant, pretty filly, lots of bone, lots of finish. She is also excellently well bred, as a glance through her parent's pedigrees will show. Suffice it to say, that every way she is up to her breeding.

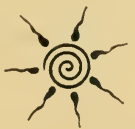




\section{MARES IN TRAINING.}

\section{HATTIE PROCTOR.}

Dark bạy mare ; foaled 1884 ; bred by Mr. Proctor, Claremont, N. $\mathrm{H}$.

Sire, VOLUNTEER BOY.

Trial, 2.27 .

Dam, Proctor MARE,

by Goldthwait Horse,

(Morgan Hunter Jr.)

Son of Morgan Hunter, by Gifford, he by Gifford Morgan; Morgan Hunter Jr.'s dam by Colby Horse, a son of the Barker Horse.

Second Dam, Daughter of Flying Morgan.

Hattie Proctor is a typically finished Morgan, fine, yet compactly made, and of grand substance on every hand. She is a nervy, resolute mare, possessed of indomitable courage and rare intelligence. With her high temperament, she is level-headed, and can undoubtedly with a season's handling, trot in $\mathbf{2 . 2 5}$.

\section{SNOWFL AKE.}

Gray mare; foaled 1882 ; bred by John Jones, Claremont, N. H. Sire, ALMONT EAGLE, 2.27.

Dam, Jones MARE,

by Metcalf Horse,

Son of Vt. Black Hawk.

This mare could be trained a season with prospects of entering the 2.30 list, for she is speedy, well behaved and good gaited, very reliable, and a very nice mare. 


\section{SISTER.}

Black mare ; foaled I 885 ; bred by A. W. Fairbanks, So. Cornish, N. H.

Sire, ALMONT EAGLE, 2.27.

Dam Kitty, Own Sister to Dam of Dandy.

-Sister is fast and will be a 2.30 performer, bar all accidents. She and Dandy would make a magnificent double hitch, are elegantly made and gaited alike. She will be trained in $189 \mathrm{I}$ for a record.

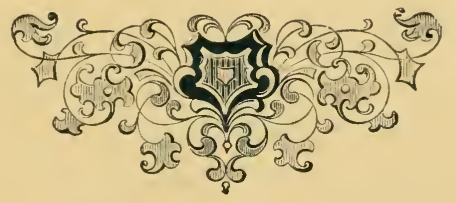




\section{GELDINGS.}

\section{CLEVELAND.}

Bay gelding; foaled $\mathrm{r} 887$; bred at Highland View.

\section{Sire, VOLUNTEER BOY.}

Dam, Nettie Goodwood, by Goodwood.

Second Dam, Nettie Burlew, by Champion, 807 .

$$
2.24 \text {. }
$$

Third Dam, NIPPER,

by Geo. M. Patchen, $2.23 \frac{1}{2}$.

Very promising, stands I5.I, and extra handsome. Will pay to develope for trotting purposes.

\section{GUIDE.}

Brownish bay gelding; foaled 1887 ; bred at Highland View.

Sire, VITTORIA, 3993.

Dam, Eudora, by Almont Eagle, 2.27 .

Second Dam, Volley's Dam.

This horse stands $15 . \mathrm{r}$, is handsome, and would with handling learn to go some. 


\section{BELLRICE.}

Bay gelding; foaled I888; bred at Highland View.

Sire VITTORIA, 3993.

Dam, Daughter of

Second Dam, Leet Mare,
Almont Eagle, 2.27.

by Abe Rogers,

Son of Black Hawk, 5 .

The Abe Rogers Horse made a record of 3.00 over 30 years ago. BELLRICE will develope into a superb, fast roadster, with possibilities of speed. He is very handsome.

\section{JARYIS.}

Black gelding; foaled I889; bred at Highland View.

Sire, VITTORIA.

Dam, FAIRY, by FLORIDA.

Second Dam, Daughter of

DAD,

By Ethan Allen, $2.25 \frac{1}{2}$.

\section{FARWLELL.}

Black gelding; foaled $\mathrm{r} 885$; bred by Mr. Farwell.

Sire, ALMONT EAGLE, 2.27.

Dam, Farwell Mare,

by LexingTON, Son of Vt. Black Hawk. 


\section{FRANK B.}

Dark bay gelding; foaled $\mathbf{r} 885$; bred by Frank Brock, Springfield, $\mathrm{Vt}$.

Sire, ALMONT EAGLE, 2.27.

Dám, Brock MARE,

by Perkins' Young Morrill.

These geldings would make very elegant gentlemen's driving horses, are handsome, bold movers, and extra stylish and nicely gaited. Frank B. is one of the most elegant large horses we ever saw harnessed.

\section{DANDY.}

Black gelding; foaled 1884 ; bred by A. W. Fairbanks, So. Cornish, N. H.

Sire, ALMONT EAGLE, 2.27.

Dam, Torsy',

by HANNIBAL,

Son of Surprise, by Vt. Black Hawk, sire of Éthan Allen, 2.25 $\frac{1}{2}$.

Second Dam, Nelly,

by RIP VAN WINKLE, By Vt. Black Hawk.

Third Dam, Farley Rosseter Mare.

\section{Untraced.}

Surprise was out of a daughter of Black Hawk, 5, hence Dandy is highly inbred to the famous Black Hawk family. He is a very elegant horse, up-headed, handsome, very pure gaited, and can undoubtedly trot in or very near 2.25 with regular track work. A Boston gentleman made a fair offer (for an undeveloped horse) last spring, but we preferred to bring him out or sell to one who would afford him a turf education. 


\section{CLAY ABDALLAH.}

Bay gelding; foaled 1885 ; bred at Highland View.

Sire, MORGAN CLAY.

Dam, Collie,

Second Dam, Carrie T., 234,

Dam of Maggie Thomas, 2.31, at 4 years.

Third Dam, Maud's Sister,

Fourth Dam, Daughter of

Fifth Dam, Daughter of

Sixth Dam, Daughter of

Seventh Dam, Daughter of by Lakeland Abdallah, i6o.

by Almont, 33 .

50 in 2.30 list.

by ABDaLlLah, I 5 .

Robt. Bruce,

By Clinton.

MuCKLe John, By Sir Archy.

Trumpeter.

Stanboul (Arabian).

\section{Morgan Clay.}

Sired by Neeley's Henry Clay, 507, son of Strader's Cass. M. Clay, Jr., he by C. M. Clay, I8; dam Schamyl, by son of Vermont Black Hawk; 2d dam by The Warner Horse, he by Long Island Black Hawk; 3d dam by Fireman, thoroughbred son of Sir William. Neeley's Henry Clay was out of Sue Letcher, by Norman, sire of Lulu, 2.14 $\frac{8}{4}$, Kate Crocket, 2.20, etc. Norman was by The Morse Horse, he by European (McNitt Horse); dam by Hambletonian, 2 (Harris), son of Bishop's Messenger; 2d dam, Mozza, by Peacock, he by Imp. Messenger.

Clay Abdallah is a grandly bred horse. He left some few colts, so we give an extension of his breeding for reference. He is now added to the list of geldings, and a very fine roadster, with promise of speed. 


\section{ECLIPSE.}

Bay gelding; foaled 1880 ; bred by Wm. Abbott, Boston, Mass. Sire, MAMBRINO DUDLEY, 2.19姺.

Sire of

Crescendo.

2.24 Gretna................... $227 \frac{1}{2}$

RINALDO..............................

Dam claimed to be, and undoubtedly was, a daughter of Blue Bull.

EcLIPSE is not for sale, being Mrs. Moody's road-horse, and could not be replaced at any cost were we to part with him.

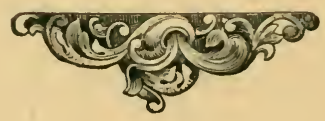




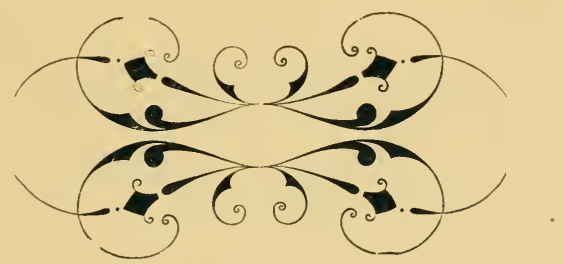


$+6$ 


\section{SUPPLEMENT}

Stock Purchased since Catalogue was Issued, too late for classification.

\section{ESTELLA.}

[STANDARD, RULE 6.]

Brown filly; foaled i889. Purchased of M. J. Hendricks, Union Springs, New York. Owned at Highland View.

Sire, CLAY KING, 2964.

Record 2.30.

Sire of King Clay, by SAYres' HARry Clay, out of MOdesty, 2.26, by Tom Wonder; 2 d dam Wells Star, by Anerican Star (dam also of ARTiLLERY, 2.2I $\frac{1}{2}$ ); Clay King's dam, AmY, $220 \frac{1}{4}$, by Volunteer, 55, out of Belle Brandon (dam of Guv. S'Prague, $2.20 \frac{1}{4}$, Wilmer, 2.30), by H.1MBLETONIAN, IO.

Dam, Nelly,

Second Dam, Daughter of Third Dam, Daughter of

Third Dam, Daughter of by Wir. M. RYSDYK, 5703 , Sire of Lady Whitefoot, 2.1 $18 \frac{1}{4}$.

LONG ISLAND.

Champion, 807 ,

Sire of Nettie Burlew, 2.24, and 7 others.

Thoroughbred Tormentor.

Estella was purchased to get the blood of Belle Brandon (dam of Gov. Sprague, $2.20 \frac{1}{4}$, sire of 24 in 2.30 list), one of Hamble-

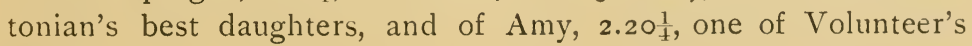


producing and performing daughters; together with the blood of the great broodmare, Well's Star, dam of the great stallion, Artillery, $2.2 \mathrm{I} \frac{1}{2}$, and Modesty, 2.26. She is a wonderfully well-bred filly, a superior individual, and bred to Evolutio will produce one of the very highest bred animals to be procured even in these days of advanced breeding. Is of good size, and well adapted at maturity for broodmare use.

\section{NYDIA.}

Bay filly; foaled 1890 ; bred by Francis B. Mitchell, Esq., New York City. Purchased through M. J. Hendricks, Union Springs, N. Y., by Highland View Farm.

\section{Sire, WATERLOO, 4716, 2.23 品.}

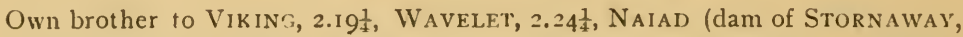

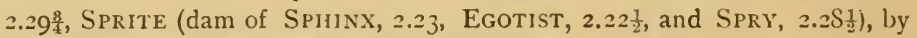
Belmont, out of IVATERwitch, by Pilot, JR.

Dam, Merelda,

by TrEMONT, ${ }_{5} 565,2.28 \frac{1}{2}$,

Sire of Junemont, 2.18冬, Bellerene.

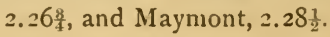

Second Dam, Jessie Haynes, by Don J. Robinson, 45 I,

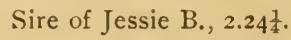

This filly is destined to become a broodmare at Highland View, and when mated with Rex Nutwood the produce will carry two strains to Pilot, Jr., through his best daughters, Miss Kussell, dam

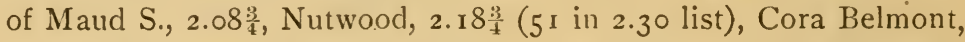

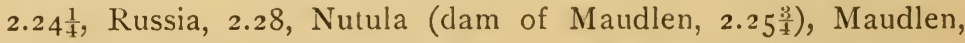
2.25 $\frac{3}{4}$, Lord Russell, (sire of 3 in 2.30), Mambrino Russell (sire of 5 in 2.30 , and grandsire of 1 at 2 years), and Waterwitch, the dam of Viking, 2.1 $9 \frac{1}{4}$, Mambrino Gift, 220 ( 7 in 2.30), Scotland, $2.22 \frac{1}{4}$,

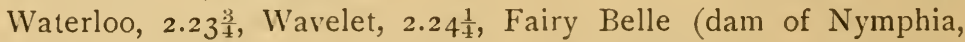

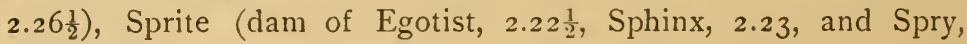
$2.28 \frac{3}{4}$ ), Naiad (dam of Stornaway, 2.29:3) ; this will make quite a trotting inheritance, and that is what we are aiming to secure, along with individuality. She is a nice filly every way. Don J. 
Robinson was by Marshall Chief, 452, sire of Dr. Lewis, 2.24,

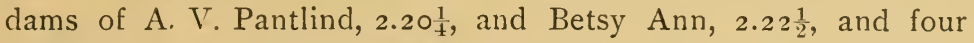
sons, sires of 2.30 horses. Robinson's dam, Lady Bates, by Hambletonian, ro; 2 d dam, Belle of Richmond, by Bathgate's Norman. Marshall Chief is a grandson of Vermont Black Hawk, and out of a Morgan mare.

Tremont was by Belmont, out of Virginia, by Abdallah, I5 ; 2d dam, Grey Goose (dam of Champagne, 2.30), by Nottingham's Norman; 3d dam by Brown Consul. We get the blood of Belmont doubled, as Waterloo was a son of that great sire. There are producers in every line of this filly's rich pedigree, and it will be very discouraging if she herself doesn't become a great speedproducer when she shall be bred to Rex Nutwood. The produce of Belmont are breeding on very commendably.

\section{WITCHCRAFT.}

Bay filly; foaled 1890 ; bred by R. M. Stone, Esq., Marcellus, N. Y. Purchased through M. J. Hendricks, by Highland View Farm.

Sire, WATERLOO, 4716.

Record $2.23 \frac{3}{4}$.

Dam, Marella.

by Sir Walkill, i 547 ,

(Own brother to Orange Girl, 2.20), sire of Walkill Boy, 2.24, and Claudia, 229.

Second Dam, Valley Belle, by Mambrino Boy, 844 ,

Sire of dams of Axtell, 2.I2, and Allerton, 2.1 $3 \frac{1}{2}$, Champion Stallions at 3 years and 4 years old.

Third Dam, Daughter of Sir William Wallace. (Bohannon's.)

Fourth Dam, Mambrino Belle, by Mambrino Chief, ir, Sire of Lady Thorne, 2.1 $\frac{1}{4}$, and Woodford Mambrino, $2.21 \frac{1}{2}$, etc. 
In all the stud-book it is very doubtful if the superior to this filly in matter of great broodmare lines could be found. She has three lines to Mambrino Chief, Ir, the great Hambletonian-American Star cross the blood of Mambrino Boy, sire of dams of the greatest three-year.old, Axtell, 2.12, and greatest four-year-old stallion, Allerton, 2.1 $3 \frac{1}{2}$, both of which stand at a service fee of $\$ 1.000$; then to the remarkable producer, Waterwitch. It is wonderful, but the sort of animals we consider best adapted to produce trotters, and what we have aimed to secure, to give opportunity to our young stallions, Rex Nutwood and Evolutio. Comment on Waterloo has already been made, so it is not necessary to repeat it here.

\section{HESTER.}

Sire, ALMONT EAGLE, 2.27.

Dam, Leet Mare,

by The Sheldon Horse,

Son of Morgan Empire, he by Empire State, son of Duroc, Morgan Empire's dam, by Woodbury, son of Justin Morgan.

This pedigree is short, but a rich commingling of Abdallah-Mambrino Chief blood with that of the stout, hardy Morgan, and tracing direct to the fountain head of the founder of the great family Justin Morgan. She is a handsome, highly-finished mare, and speedy as well.

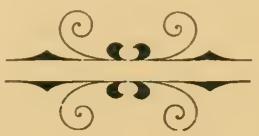




\section{QUEEN WLILKES.}

[STANDARD, RulE 6.]

Bay filly; foaled July I3, I89o; bred by J. W. Willis, M. D., Waltham, Mass.

\section{Sire, SIR WALTER, JR., $2.18^{\frac{1}{4}}$.}

Dam, Lady Ashley,

Second Dam, Maragold,

by Kentucky Wilkes, $2.2 \mathrm{I} \frac{1}{4}$, Sire of Virginia Evans, 2.24, and Astoria, 2.30.

by Black Cloud,

Own brother to Lady Stout, 2.29, and sire of Charmer, 2.27.

Third Dam, Polly Farragut, by Admiral Farragut,

Dam of Theresa, $2 \cdot 30 \frac{1}{2}$, and Ethan

H. Drew, $2.33 \frac{1}{2}$, mile track.

Fourth Dam, Daughter of
Son of Young Quaker, by Harris's Hambletonian.

Young Morrili, i 18.

Sire of Fearnaught, $2.23 \frac{1}{2}$, etc.

Sir Walter, Jr., 2.I $8 \frac{1}{4}$, was much faster than the record, and showed a trial at five years of $2.17 \frac{1}{2}$ over Fleetwood track. He is by Sir Walter, 2.24 $\frac{1}{4}$, sire of three in 2.30 list, and out of a daughter of the great broodmare sire, American Clay, the rest of his breeding tracing directly to the best thoroughbred sires. Sir Walter,

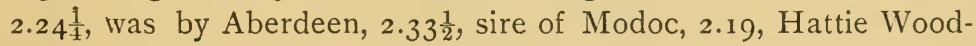
ward, 2.1 $5 \frac{1}{2}$, and many others, and his dam by Edward Everett, sire of Judge Fullerton, 2.18, and many others. Aberdeen, 2.33 $\frac{1}{2}$, was by Hambletonian, Io, out of the fastest daughter of American Star, I4, Widow Machree, 2.29, one of the gamest mares ever trotted; so pronounced by the late Dan Mace, and other excellent authorities. We not only get the greatest Hambletonian-Star cross, but the Hambletonian-Clay strain, from which came Electioneer, Geo. Wilkes, and St. Julien, among the trotters. Note the 
speed progression : $2.33 \frac{1}{2}, 2.24 \frac{1}{4}, 2.18 \frac{1}{4}$, and she is gaited so to give the hope that these figures may yet be lowered. On the dam's side we get Kentucky Wilkes, $2.2 \mathrm{I} \frac{1}{4}$, on the best of Geo. Wilkes' sons, and is producing trotters, though but a short while in the stud. The second dam is by Black Cloud, son of the great broodmare sire, Mambrino Patchen, $5^{8}$, and a horse, own brother to Lady Stout, 2.29, the first to attain that record as a three-year-old. Black Cloud's dam produced Lady Stout, 2.29, Black Diamond,

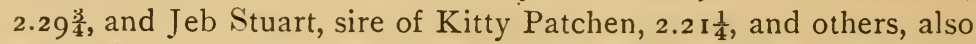
Mambrino Time, sire of two in 2.30, and the dam of Silverone, 2.19 $\frac{3}{4}$, also Black Cloud, sire of Charmer, 2.27. Polly Farragut, her third dam, is a producer of speed, for Theresa trotted in $2.30 \frac{1}{2}$, while heavy in foal, and Ethan $\mathrm{H}$. Drew has a record of $2.33 \frac{1}{2}$ on a half-mile track. We consider that in point of breeding QueEN WiLkES is in the very front rank; few there are carrying the blood of the great sires, Geo. Wilkes, Hambletonian, American Star, and Mambrino Patchen, as well as the American Clay outcross. She is what we have tried hard to secure for the Highland View Stud.

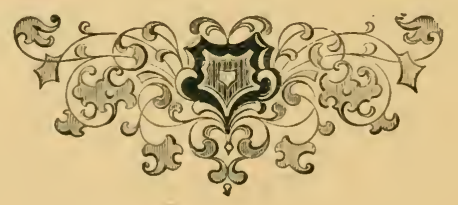




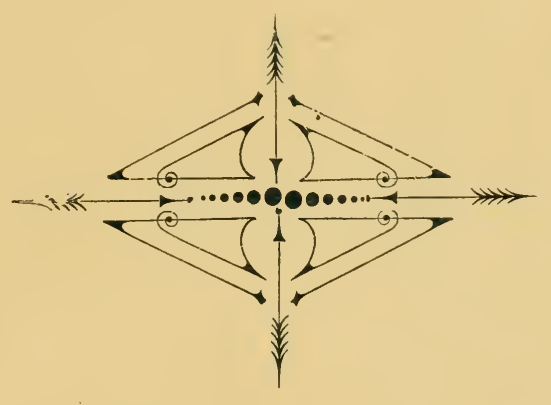




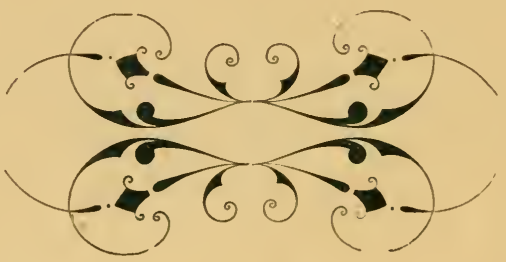




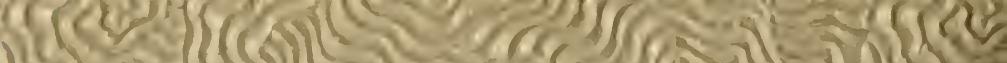

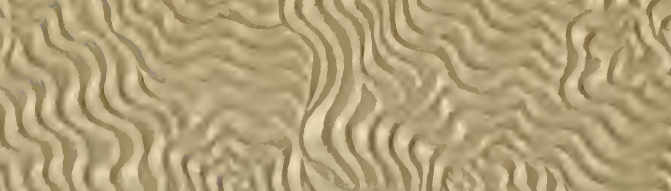

IL)

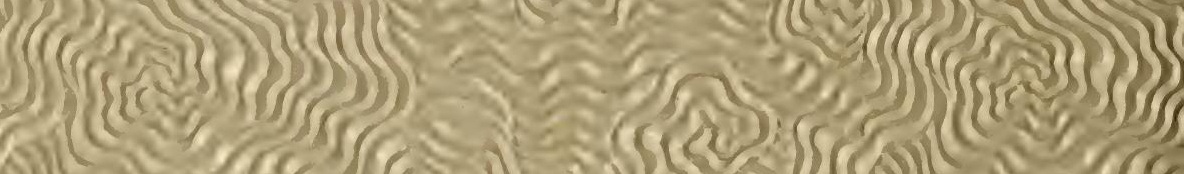
). (a) Min

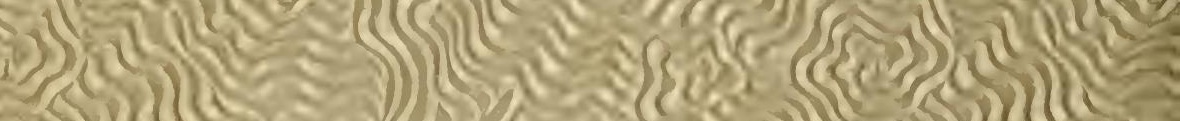
2ख(

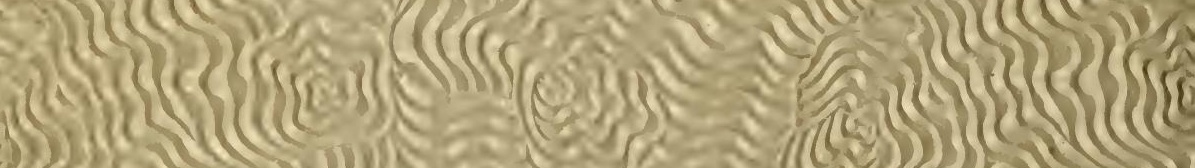
(सr

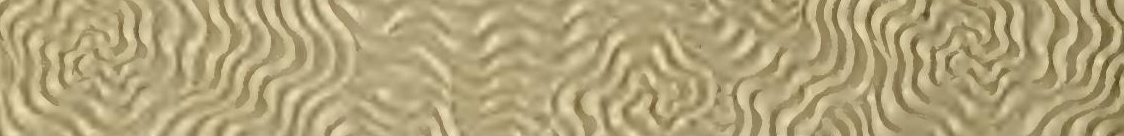
แ3. (n) wis Isc)

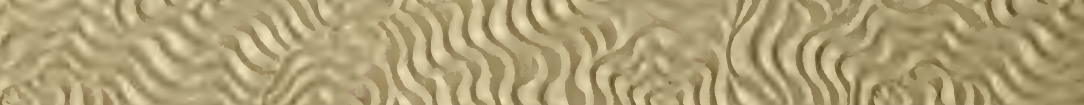

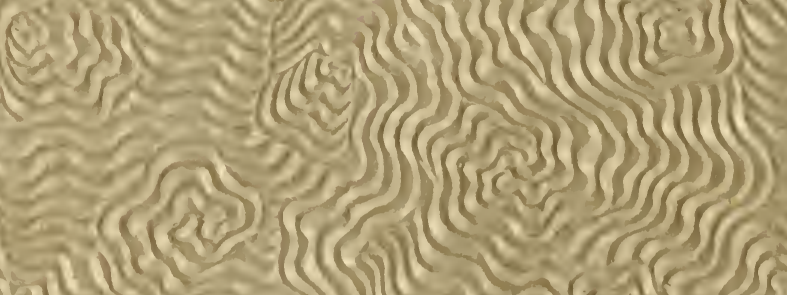
(2)

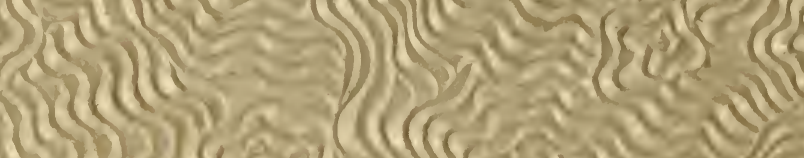
बिखि iv) ${ }^{2}(\mathrm{~m})$

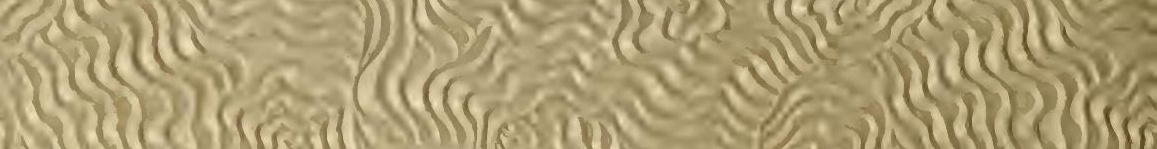

